\title{
Employers' Liability and Workers' Compensation: England and Wales
}

\author{
Richard Lewis
}

\section{Introduction}

\section{A. The basic system of compensation and liability}

An employee injured at work in the UK is able to claim not only no-fault $\mathbf{1}$ social security benefit from the state under the industrial injuries compensation scheme, but also damages from the employer if liability in tort can be established. Use of one system of compensation does not lead to exclusion from the other; there is no 'employer privilege' preventing an employee claiming from both workers' compensation and tort.

This chapter describes and compares both of these systems of compensa- 2 tion. In this regard it is very unusual and breaks new academic ground. Although in the UK there is a very extensive literature about the law of tort, there is very little written about workers' compensation under the state scheme. In large part this is because lawyers are ever-present in tort claims whereas they are very rarely involved in applications for social security benefits. By comparing the two regimes, this chapter sets out a context for work injury compensation which has not been made in recent years. In particular, the comparative statistical analysis offers a new treatment. In many respects, albeit in this summarised form, this chapter provides a unique source.

Entitlement to compensation under each regime is founded upon very 3 different bases. In general, whereas the state scheme requires only proof of a work-related injury irrespective of how it occurs, the tort claim is usually founded upon proof of another's wrongdoing. However, this requirement to prove fault is commonly undermined in tort when employers are held strictly liable for breaches of duty placed directly upon them.

When comparing the benefits offered, the differences are more apparent. 4 The state scheme provides benefit more quickly than the tort system pays 
damages, but it does not provide full compensation. A major difference is that the state scheme does not compensate for financial losses such as loss of earnings or the costs of care. Nevertheless claimants turn to this benefit, together with others in the social security system, as their first sources of support. In this sense, any later action begun in tort may be seen as merely supplementary to the benefit claim. However, it is only the tort system that aims to return the claimant as far as is possible to the position he was in before the injury, and only tort is able to compensate for financial loss. In awarding this full compensation, tort pays damages in the form of a lump sum which, in catastrophic injury cases, can amount to millions of pounds. It is then that the benefit claim may be seen as only peripheral to the tort award.

5 However, if we look at total expenditure and the number of recipients of compensation a different picture emerges. The annual expenditure upon each scheme is now approximately the same. ${ }^{1}$ On the one hand, there are twice as many new claims made in tort than under the industrial scheme; ${ }^{2}$ on the other hand, there are four times as many no-fault pensions in payment as there are annual awards of lump sums in tort. The schemes are therefore of similar historical importance, and although the significance of tort has increased, neither scheme should be seen as necessarily inferior to the other.

\section{Tort}

6 Although the origins of tort liability lie in pre-medieval times, the first reported case of an employee suing his employer for personal injury was not until 1837. ${ }^{3}$ The claim failed, and few such actions were brought in that century and much of the next. There were many reasons why workers did not sue. It is true that the legal rules were very much against them: proving that another was at fault for their injury was fraught with uncertainty and, if wrongdoing was established, workers faced several draconian defences which enabled employers to avoid liability. Judges 'quashed nearly every innovative attempt to create law favourable to workers'. ${ }^{4}$

1 No 132.

2 No 129.

3 Priestley v Fowler (1837) 3 Meeson \& Welsby's Exchequer Reports ( $\mathrm{M} \& \mathrm{~W}$ ) 1; AWB Simpson, Leading Cases in the Common Law (1995) 128. Employees did sue for unpaid wages and other injustices. MA Stein, Priestley v Fowler and the Emerging Tort of Negligence (2003) 44 Boston College Law Review (BC L Rev) 689 at 725.

4 MA Stein, Victorian Tort Liability for Workplace Injuries [2008] University of Illinois Law Review 933 at 983. 
A more important obstacle than these legal rules which limited claims was the 'living law'. ${ }^{5}$ That is, the real difficulties for employees lay not so much in tort textbooks but in the realities of workplace power and relations, and in people's attitudes towards misfortune. For example, many workers never thought of suing because they were not even aware that a wrong had been done to them. An accident was an everyday occurrence and part of their way of life, and the risk of injury was seen as in the hands of Fate rather than the employer. If workers were aware that a wrong had been done, they were often ignorant of the possibility of bringing a claim. Those who knew of the tort system found it very difficult to get legal advice. If they did sue, they faced the prospect of incurring legal costs. A more significant deterrent was the likelihood that a tort claim would lead to the loss of work-related benefits such as employer's sick pay, or continued employment in an easier job, or medical treatment from work doctors. Suing an employer 'often meant antagonising the most powerful men in the region and jeopardizing not only one's employment prospects, but also one's housing, church membership and even access to town poor relief'. ${ }^{6}$ Nor could workers easily endure the lengthy, complicated and uncertain litigation process itself. Their claims then were opposed by the best lawyers and by morally questionable defence strategies.

The final difficulty faced by workers was that they often needed what tort $\mathbf{8}$ could not supply: urgent recompense to replace their wage loss. As a result, they were all too ready to accept any money that was on offer. In cases where the employer offered to pay some sickness benefit or provide medical care a receipt invariably had to be signed and this released the employer from any liability in tort. Workers were thus contractually barred from pursuing a claim. A similar result was achieved by legislation if a worker accepted worker's compensation. By 'electing' to accept the nofault benefit the worker was required by statute to give up his right to sue for damages in tort. In reality the worker had little choice: no-fault compensation offered the certainty of an immediate fixed payment, whereas damages were but a remote prospect for an uncertain sum via an unpredictable route. Overall the tort system in the late nineteenth and early twentieth centuries has therefore been described as one of 'noncompensation'?

5 L Friedman, Civil Wrongs: Personal Injury Law in the late Nineteenth Century [1987] American Bar Foundation Research Journal (Am B Found Res J) 351, reflected in a British context in PWJ Bartrip/SB Burman, The Wounded Soldiers of Industry (1983).

6 JF Witt, The Accidental Republic (2004) 55.

7 Friedman [1987] Am B Found Res J 351. 
9 Gradually all this changed. Not only was there a shift in workplace power relations and the 'living law' such as to make tort claims more likely, but also the tort rules themselves were eased. For example, the defences were imposed less readily and their effects made less severe; and in 1948 the bar was removed so as to allow claimants to sue in tort as well as claim the nofault industrial injuries social security benefit. By then, not only did workers have a different perspective upon accidents compared to their nineteenth century counterparts, but they had also gained the assistance of trade union funded lawyers. As a result, from the second half of the twentieth century litigation substantially increased. By 1978 work accident claims had risen to constitute almost half of all personal injury actions brought. However, with the continued rise of road accident claims, work injuries have since declined in importance and now number less than one in ten of all tort claims. Nevertheless they still account for about 78,000 claims a year.

\section{Workers' compensation}

10 In the nineteenth century the failure of the common law to compensate injured workers on any scale was a major reason for the creation of a nofault system outside of tort. The Workmen's Compensation Act 1897 imposed a duty on employers to make limited payments to the victims of industrial accidents irrespective of whether those injuries were caused by wrongdoing. ${ }^{8}$ Employers were left to arrange their own insurance to pay the cost of these claims. This scheme has been called the 'pioneer of social security' because it was the forerunner of broader welfare measures. ${ }^{9}$ Its basic structure lasted over fifty years until the state took full responsibility for all payments in 1948 and private insurers were then excluded from involvement with the scheme. ${ }^{10}$ Because of the new no-fault system which was being put in place, it was questioned whether access to tort for work claims should continue, but eventually the worker's ability to sue at common law was retained. 11

8 The nineteenth century history is traced in Bartrip/Burman (fn 5) and in Stein BC L Rev 689 at 725.

9 Social Insurance and Allied Services: Report by Sir William Beveridge (1942, cmd 6404).

10 National Insurance (Industrial Injuries) Act 1946.

11 For the debate about whether tort as an 'alternative remedy' should be retained see PWJ Bartrip, Workmen's Compensation in Twentieth Century Britain (1987) ch 10 and Report of the Departmental Committee on Alternative Remedies (1946, Cmd 6860), chaired by Sir William Monckton. 
Since 1948, in spite of a series of reforms designed to reduce expenditure, cut overlapping benefits and improve efficiency, the no-fault scheme has proved surprisingly resilient. In 1978 it was still paying out three times as much as the tort system in total, and there were seven times as many beneficiaries.12 It was not until 1995 that tort paid out more money per year than did the industrial scheme, and the scheme continues to compensate four times as many workers as tort each year. However, most of these beneficiaries first started receiving their pensions some years ago, and now tort compensates twice as many new claimants per year than the industrial scheme. In historical terms, therefore, the schemes can be seen as of comparable importance but it is tort that is the more significant nowadays.

\section{Why preferential compensation for workers?}

There is a fundamental question which has influenced the history and present position of work claims: can the preferential treatment given to workers compared to other injury victims be justified? The industrial injuries scheme privileges workers by making available benefit which cannot be claimed by those not injured in the course of employment. In tort, although the compensation is assessed the same whether or not a work injury is involved, liability is easier to establish in work cases because strict duties are commonly imposed upon the employer. The advantage given to workers in both of these areas has been challenged.

In the landmark report in 1942 on the future of the welfare state it was

said that 'a complete solution is to be found only in a completely unified scheme for disability without demarcation by the cause of disability'.13 However, three arguments on balance eventually led to the retention of the special scheme of compensation for work accidents. These were that -

- many industries vital to the community were dangerous and it was desirable that those working in them should have special protection;

- those disabled at work were working under orders; and

- only if special provision were made could an employer's liability at common law be restricted to the results of his negligence.

12 Report of the Royal Commission on Civil Liability and Compensation for Personal Injury (1978, Cmnd 7054), chairman Lord Pearson vol 1 para 772.

13 Social Insurance and Allied Services: Report by Sir William Beveridge (1942, Cmd 6404) para 80: 'If a workman loses his leg in an accident his needs are the same whether the accident occurred in a factory or in the street.' 
14 Each of these arguments looks outdated today. The first can be countered by noting that the preference applies to all industries not just the dangerous ones. In addition, the award of a limited pension after injury is now seen as little, if any, incentive to undertake risky work. There is a sharp contrast here with 'danger money' paid before any injury occurs. Against the second argument it can be argued that there is a great deal of individual autonomy at work, and accidents that occur because of a specific order are not common. The third argument has been entirely overtaken by events. Retaining the industrial scheme in no way has led to a reduction of liability at common law or to liability being confined to where there is fault. Instead tort claims have increased considerably, many of them based on strict liability.

15 In practice the preference was retained because of powerful political arguments and a desire to avoid antagonising the labour movement and the trade unions. The International Labour Organisation has concluded that the distinction between work and other accidents is increasingly anomalous and traditional practice is the main obstacle to change. ${ }^{14}$ One text describes the preference as 'simply indefensible'. ${ }^{15}$ However, to replace the labyrinthine maze of benefits presently facing the disabled with a more comprehensive allowance is a difficult and expensive task. Although sympathetic to such an aim, an official report in 1990 concluded that there was still a case for retaining the industrial preference partly because of the fear that any comprehensive allowance would be too little to meet needs. ${ }^{16}$ The result is that, although the scope of the industrial scheme has been reduced in the last 25 years, it continues to operate alongside the tort system. Politically it remains a very difficult preference to remove. ${ }^{17}$ In this respect it has much in common with tort liability itself which continues to flourish in spite of criticism and the absence, in other countries, of such liability for work injury. There is no prospect in the UK of the tort liability rules being attenuated in any way, although proposed procedural changes may have profound effects.

\footnotetext{
14 The Pearson Report (fn 12) vol 3 para 1009.

15 P Cane Atiyah's Accidents, Compensation and the Law (7th edn 2006) 355.

16 Industrial Injuries Advisory Council, The Industrial Injuries Scheme and the Reform of Disability Income (1990, Position Paper No 5).

17 S Jones, Social Security and Industrial Injury, in: N Harris, Social Security Law in Context (2000) 494 .
} 


\section{B. Interaction with other institutions}

Both the tort and industrial injuries systems interact not only with each

other but also with other sources of compensation which derive either from the welfare state ${ }^{18}$ or from employers and other private organisations. ${ }^{19}$ The relationships are diverse and complex, and are considered under the particular headings below as they arise.

\section{Empirical evidence}

There is a marked difference between the sources of information about tort, on the one hand, and the industrial scheme, on the other. The voluminous materials describing the general principles of the law of tort can be contrasted with the paucity of information about the state benefit. Lawyers earn much money from claims for personal injury, and tort is a foundation subject studied in every law school. As a result there is a vast academic and practitioner literature in law journals, and new tort textbooks are produced every year. By contrast, lawyers have very little involvement with the industrial scheme, and it is very rarely examined by law students. The last book describing its operation was that published by the present author twenty five years ago. ${ }^{20}$ There is almost no periodical literature. As a result, information about the scheme and analysis of it derives predominately from official sources.

The descriptions given here of the actual operation of these very different systems of compensation relies upon empirical evidence gathered from a variety of sources, a few key ones being footnoted below. Some of these sources are official government reports about either the tort ${ }^{21}$ or the industrial injuries scheme, ${ }^{22}$ whereas others are the result of private

18 R Lewis, The Impact of Social Security Law on the Recovery in Tort of Damages for Personal Injury, in: U Magnus (ed), The Impact of Social Security on Tort Law (2003).

19 R Lewis, The Relationship between Tort Law and Insurance in England and Wales, in: G Wagner (ed), Tort Law and Liability Insurance (2005).

20 R Lewis, Compensation for Industrial Injury (1986).

21 The Pearson Report (fn 12).

22 Department for Work and Pensions, Industrial Injuries Benefit Quarterly Statistics, table 1.2 at <http://research.dwp.gov.uk/asd/asd1/iidb/index.php?page=iidb_quarterly_dec09> Department for Work and Pensions, Benefit Expenditure Tables - Medium Term Forecast, at $<$ http://statistics.dwp.gov.uk/asd/asd4/index.php?page=medium_term $>$. 
research. ${ }^{23}$ A few key secondary sources on tort ${ }^{24}$ and the industrial scheme ${ }^{25}$ are also footnoted.

\section{Workers' Compensation}

\section{A. Scope of cover}

\section{Workers covered}

19 The industrial injuries compensation scheme only compensates those who are 'employed earners'. This does not include those who are self-employed. This means that whereas the 25 million people in the UK who are employed by others under a contract of service are covered, about 4 million people who work for themselves are not. ${ }^{26}$ Although the selfemployed may be considered just as deserving of compensation, concern has been raised that if they were brought within the industrial scheme it would create uncertainty because of the greater difficulty in identifying whether they are in the course of their employment when they are injured. A narrower recommendation that at least those self-employed working in construction and agriculture be brought within the scheme has not been implemented. ${ }^{27}$ This is in spite of the fact that many of those engaged in these occupations are not really self-employed in any meaningful way.

20 The distinction between an employee and independent contractor is explored further below in relation to employers' liability claims. ${ }^{28}$ If we compare tort liability we find that the primary common law and statutory duties are similarly only owed to employees and not to the self-employed,

23 Empirical studies are extensively referenced in D Dewees/D Duff/M Trebilcock, Exploring the Domain of Accident Law: Taking the Facts Seriously (1996). For statistical analyses see, UK Personal Injury Litigation 2009, Datamonitor Report, December 2009 and International Underwriting Association of London, Fourth UK Bodily Injury Awards Study (2007).

24 Atiyah's Accidents (fn 15); WVH Rogers, Winfield and Jolowicz on Tort (18th edn 2010); $S$ Deakin/A Johnston/B Markesinis, Tort Law (6th edn 2008); M Lunney/K Oliphant, Tort Law (4th edn 2010).

25 Lewis (fn 20); NJ Wikeley/AI Ogus/E Barendt, The Law of Social Security (5th edn 2002); Bartrip (fn 11); JC Brown, Industrial Injuries (1982), the Department for Work and Pensions, Decision Makers' Guide offers detailed analysis of the scheme in a series of publications at $<$ http://www.dwp.gov.uk/publications/specialist-guides/decision-makers-guide/ \#vol11>.

26 Office for National Statistics, Labour Market Statistics <http://www.statistics.gov.uk/ pdfdir/lmsuk0910.pdf >

27 Industrial Injuries Advisory Council, Report (1993, Cm 2177).

28 No 104 below. 
although at times the statutory duties can also extend to visitors and others. However, where the tort action is based on vicarious liability anyone who is injured can sue. In that respect tort has wider coverage because claimants can include not only those in business for themselves but also, for example, visitors to the workplace or members of the public injured on the roads or elsewhere by the negligent employee when doing his job.

Employed earners under the industrial scheme are covered from their first day at work, and they do not have to qualify, as they do for certain contributory benefits, by paying a minimum number of payments into the national insurance scheme. Those serving in the armed forces are not covered by the scheme, but are entitled to their own special benefits.

There are territorial limits to the industrial scheme as with any regime of social security. However, many of those injured abroad are now covered. These include those for whom national insurance contributions are paid; those in European Union countries, or countries with which Britain has a reciprocal agreement; and airmen, mariners and others.

\section{Spatial, temporal and other limitations}

As we shall see below there are two basic routes to gaining entitlement to benefit. A claimant must show that the injury is either a prescribed disease or a 'personal injury caused ... by accident arising out of and in the course of employment ....29 These last words, first used in the Workmen's Compensation Act 1897, have been adopted by English speaking jurisdictions throughout the world. It has been suggested that the phrase has given rise to more litigation than any other in the English language. ${ }^{30}$ Its uncertain scope is not the result of poor legislative drafting, but is inherent in the phrase; it is caused by the very attempt to distinguish work injuries from others.

\section{a) The accident must 'cause' the injury}

The claimant must show that the industrial accident is not only a necessary condition which caused the injury (causa sine qua non) but also that it is a cause of some potency which contributes materially to the injury (causa

29 Social Security Contributions and Benefits Act 1992 s 94 (1).

30 Departmental Committee Report on Workmen's Compensation (Holman Gregory Report) (1920, Cmd 816) para 29. 
causans). However, the industrial accident need not be the sole or even the predominant cause of injury. For example, if a heart attack is suffered at work the crucial question is 'was it the disease that did it, or did the work he was doing help in any material degree?' 31

25 To further illustrate the issues that can arise we can examine how the scheme deals with susceptibility to injury before the industrial accident occurs. The pre-existing non-industrial condition or weakness could be treated in three distinct ways:

- It could be held to be the only material cause of injury. This occurred where a degenerative disc condition gave rise to a spinal collapse which just happened to take place at work. ${ }^{32}$ No entitlement to benefit then arose.

- It could be held not to be a material cause of injury at all. This happened in a case where the disc collapsed as a result of lifting something at work. ${ }^{33}$ Here there was full entitlement to benefit because the industrial cause was held to be the sole legal cause of injury.

- Finally, it could be held to be a contributory cause of the injury among other, industrial causes. Here, there could be a reduction in the assessment of disablement to take account of the non-industrial condition.

26 If the injury is caused by coming into contact with the work premises, it has been held that the employment will be considered to be the cause even if the claimant fell as a result of high blood pressure, his artificial leg, his carelessness, or something else unexplained. ${ }^{34}$

\section{b) The accident must arise 'out of' employment}

27 In order to exclude from the scheme injuries which result from ordinary risks faced by the public at large, this phrase requires accidents to be caused in some way by work. However, it has only rarely led to the refusal of benefit. Statute prescribes that certain causes of accidents are deemed to arise 'out of' employment provided that the accidents were also in the course of employment and the claimant did not contribute to them..$^{35}$ This applies to accidents caused by:

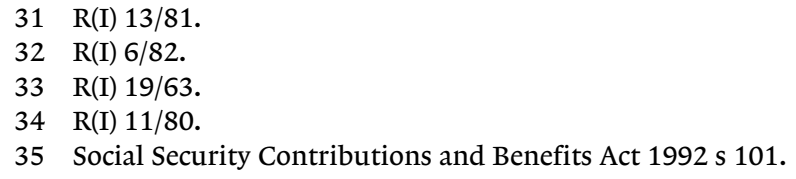


- Another's misconduct - such as an assault by strangers irrespective of whether the claimant was singled out because of his job

- Another's skylarking or negligence - so that a claim may succeed if injury is caused by a fellow employee who is either a practical joker or simply careless

- Animals - as where a door to door agent fell over a dog at the property he was visiting 36

- Being struck by lightning or any object

\section{c) The accident must arise 'in the course of employment'}

Usually the relationship between the accident and the work is obvious. 28 However, difficulties can arise in a significant number of cases because of the varied nature of employment; there may be uncertainty as to what exactly the claimant was employed to do, or the discretion that he may have had to do it. The boundaries of when work begins and ends, or is interrupted, can be difficult to draw. The scheme attempts to do so by requiring that accidents arise 'in the course of employment'. ${ }^{37}$

This phrase is notorious. One judge suggested that it has 'been worth - to lawyers - a King's ransom'. ${ }^{38}$ It has accounted for over half the litigation upon the scheme. Although it may appear that the extensive body of caselaw interpreting the phrase only adds to the confusion, in fact many of the cases can be confined to their own facts and are of limited value as precedents. By contrast there are a few key decisions which repay study because they offer general guidance concerning the factors which should be considered when determining the scope of the scheme. Even these cases, however, emphasise that no single factor is to be taken as conclusive. ${ }^{39}$

Broadly, the course of employment gives rise to questions based upon the time, place, and the activity being pursued by the claimant when he was injured. Three basic questions then arise:

\section{i) Did the accident occur during work hours?}

The limits of work cannot be defined by the written terms of contract alone: some allowance can be made for the claimant to be at work both

36 R(I) $13 / 60$.

37 Lewis (fn 20) 50-89, Wikeley/Ogus/Barendt (fn 25) 726-743.

38 Lord Denning in $R v$ National Insurance Commissioner, ex parte Michael [1977] 2 All England Law Reports (All ER) 420.

39 Nancollas $v$ Insurance Officer [1985] 1 All ER 833. 
before and after the set hours in the contract. For example, a worker who arrived half an hour early to change into her work clothes and go to the canteen was held to be within employment at that time. ${ }^{40}$ By contrast, someone who arrived ninety minutes early to avoid the rush hour was outside the scheme. ${ }^{41}$ Refreshment breaks on the employer's premises are almost always protected. Workers injured when 'on call' cause particular difficulties: are they standing by to be called back to duty and thus outside of the scheme, or are they performing their duty of standing by? 42

\section{ii) Did the accident occur at the place of work?}

32 The precise place of work sometimes can be difficult to locate although it generally includes, for example, access to the area where the claimant has been or is about to work. A 'public zone' test helps to determine the limit: the claimant usually must be in the area from which the public are excluded. This was the case where a seaman, in boarding his ship, was injured on a private jetty which he had permission to use but not the public at large. ${ }^{43}$ Whether the employer owns the land upon which the accident happens is an important although not conclusive factor. The further away the claimant is in time and space from the hours and place of employment, the more likely it is that the risk is shared by the general public and is outside the industrial scheme. Although more difficulties arise where the claimant is peripatetic, claims can still succeed as where a social worker was injured descending a common staircase in a block of flats having concluded her visit to one of the properties. ${ }^{44}$

\section{iii) Did the accident occur whilst the claimant was doing something which was part of his employment or reasonably incidental to it?}

33 If so, the employment could be extended beyond the usual hours or place of work; if not, it could interrupt the employment and place the claimant outside the scheme. Relevant questions include whether the employee had implied permission and whether the employer knew what

$40 \quad R v$ National Insurance Commissioner, ex parte East [1976] Industrial Cases Reports 206.

$41 \mathrm{R}(\mathrm{I}) 3 / 62$.

$42 \quad \mathrm{R} v$ National Insurance Commissioner, ex parte Reed (1980) appendix to $\mathrm{R}(\mathrm{I}) 7 / 80$.

43 Northumbrian Shipping Co v McCullum (1932) 101 Law Journal Reports, King's Bench New Series (LJKB) 664.

$44 \mathrm{R}(\mathrm{I}) 3 / 72$. 
was being done. The contract of employment itself is rarely helpful in determining the limit. The criteria for deciding the question have changed since workmen's compensation first began: an accident can now be accepted as arising out of and in the course of the employment if the person is doing something which is reasonably incidental to their employment even though they may have been doing it for purposes of their own.

What may be considered incidental to employment is better understood when related to particular cases illustrating the relevant factors. The following examples have been chosen either because they involve the most common problems, or because they involve extensions of the course of employment which have been laid down by statute.

\section{d) Interruptions or breaks in work}

If the claimant is injured whilst acting reasonably during a break in work $\mathbf{3 5}$ at his employer's premises the accident is likely to be within employment. Permitted activities have included not only going to the toilet or the canteen, but also going to a union meeting, ${ }^{45}$ a day release class ${ }^{46}$ or even to play sport in certain circumstances. ${ }^{47}$ Relevant factors are: 48

- The nature of the employment

- The duration of the break

- The place of the accident

- Whether the employer consented to the activity

- Whether the activity is in the employer's interest.

By contrast, if the claimant acts unreasonably he could fall outside 36 employment. This happened where a factory worker was hit by a truck whilst in a queue to use a booth in order to smoke a cigarette. ${ }^{49} \mathrm{He}$ was still in the queue even though his scheduled break had ended five minutes earlier. By deliberately going against instructions and not returning at the end of the break he was held to be avoiding work and to be outside employment. The decision appears harsh, but statements

\footnotetext{
$45 \quad \mathrm{R}(\mathrm{I}) 63 / 51$.

$46 \mathrm{R}(\mathrm{I}) 2 / 68$.

47 R(I) $13 / 66$ contrast $R v$ National Insurance Commissioner, ex parte Michael [1977] 2 All ER 420.

$48 \mathrm{R}(\mathrm{I}) 4 / 67(\mathrm{~T})$.

49 Re Culverwell [1966] 2 Queen's Bench (QB) 21.
} 
made in the case also support a less strict approach: the judge considered that generally a claimant would be within employment if injured at his place of work and during work hours by a risk incidental to employment even though he may not be doing his actual work but, for example, chatting to a friend or smoking. Even a negligent or deliberately disobedient act would not necessarily remove the claimant from the course of employment unless he was doing something different from what he was employed to do.

\section{e) Travelling and commuting cases ${ }^{50}$}

37 There are almost as many deaths caused by the daily journey to and from work as there are at work itself. ${ }^{51}$ As an exception to the rules in almost all European countries, the UK does not include travelling to and from work as within employment. ${ }^{52}$ 'Normally a person's employment begins when he arrives at his place of work and ends when the person leaves it...'.53 The general approach is subject to a number of wide-ranging exceptions. Clearly, for example, those with occupations requiring them to travel, such as bus or delivery drivers will be in the course of employment. Other exceptions involve those:

- Travelling in transport arranged by the employer. This is a statutory exception. ${ }^{54}$ The use of ordinary public transport will not suffice

- Travelling on a specific journey as instructed by the employer

- Travelling on the employer's property or in areas where the public are denied access

- Travelling in the course of a peripatetic occupation. Those who are door to door agents or home helps are therefore usually covered except when travelling to their first call of the day, or when on the way home, or if they deviate from their route for their own purposes

- Employees who are still on duty because their responsibilities continue whilst travelling. Relevant although not conclusive factors in determin-

50 R Lewis, Accidents Whilst Travelling and the Limits of Compensation for Industrial Injury (1986) 8 Journal of Social Welfare Law 193.

51 L Pickup/SW Town, A European Study of Commuting and its Consequences (1983) 106.

52 For European comparisons see the Mutual Information System on Social Protection in the EU (MISSOC) $<$ http://ec.europa.eu/employment_social/social_protection/missoc_tables_en. htm>.

$53 \mathrm{R}(\mathrm{I})$ 12/75(T).

54 Social Security Contributions and Benefits Act 1992 s 99 (1). 
ing whether the claimant is only travelling 'to' duty as opposed to 'on' duty include:

- Was the claimant being paid for time spent travelling?

- Were travel expenses to be reimbursed?

- Was the claimant carrying equipment or tools related to the job?

- Was the claimant on call or required to report at intervals to his employer?

- Was the claimant travelling by a direct route?

Proposals to change the general rule that travelling is outside employment were rejected by Government almost 30 years ago, 55 and have not been reconsidered since. The main objection was that the risks being faced were no different to those encountered by the public in general so that, if travel were included, the concept of industrial preference would be placed under great strain. In addition, the limits of the scheme would be more uncertain and the difficulties in investigating claims would increase because the employer could not provide the direct evidence needed.

\section{f) Acting in an emergency}

Employees may have to respond to unexpected events at work. If they act reasonably in doing so they will not take themselves outside the course of employment even if they attempt to do something which they may not have been employed to do. These rules apply in situations far beyond those where the emergency services may become involved. For example, lorry drivers have been held to be within employment under the emergency principle even though all they were doing was moving other goods in order to deliver their own ${ }^{56}$ or assisting another road user who had broken down and was obstructing traffic. 57

Statute also provides help for those injured in the more dramatic acts of emergency. ${ }^{58}$ If the claimant is injured at or near his place of work whilst taking emergency action to avoid people being injured or property being seriously damaged, he will be deemed to be within employment. This enabled a milkman to obtain benefit when he was injured attempting to

55 Reform of the Industrial Injuries Scheme (1981, Cmnd 8402) para 66.

56 R(I) $11 / 56$.

57 R(I) $11 / 51$.

58 Social Security Contributions and Benefits Act 1992 s 100. 
rescue children from a burning house. Under the statute there is no need for the act done to be only for the employer's benefit.

\section{Effect of the victim's contributory negligence}

41 The industrial scheme is based on no-fault. This means, firstly, that neither the employer nor any of his employees has to be shown to be at fault for the claim to succeed; and secondly, the negligence of the claimant himself will not bar entitlement to benefit. In theory, therefore, the contributory negligence defence which applies to many tort claims has no part to play in the industrial scheme.

42 However, the position is not always quite so clear cut: if the claimant's conduct creates a new or different risk from that which arises from the employment, and this risk is the real cause of the accident, then the injury will not arise out of and in the course of employment and the claim will fail entirely. This argument can have an even greater effect than contributory negligence does in tort for it may lead to the loss of all compensation. There is no way in which blame could lead to a reduction of the benefit to take account of the claimant's wrongdoing; the concept of apportionment for contributory negligence cannot apply with the result that the claim either succeeds or fails entirely.

43 The rules can be illustrated by the denial of benefit to employees who left their place of work for their own purposes, as where an employee went off to explore another part of the building. ${ }^{59}$ However, in more recent times a less strict view has been taken of the scope of employment than was the case in the past. In particular, it is now required that the claimant's conduct must create a new or different risk. This can prevent the denial of benefit as in the leading case where the claimant was injured by an explosion when he lit a cigarette near a place where, unknown to him, gas was escaping. ${ }^{60}$ The danger of such an explosion was present before the claimant used his lighter because there were other naked flames heating various machines near the escaping gas. It was held that the risk of explosion was clearly one of employment, and that, although the claimant had acted for his own purposes, he had not created a new or different risk from that which already existed. Benefit was therefore payable. 


\section{Acting contrary to orders or rules}

A distinction is drawn between orders which define what work is to be $\mathbf{4 4}$ done, and those which merely describe how it is to be carried out. The former is more likely to limit the course of employment so that contravening clear orders concerning what work is to be done could prevent entitlement arising. However, there is a legislative provision which further protects claimants here because it deems accidents to be within employment if they would have been so had it not been for the claimant breaking regulations or orders. ${ }^{61}$ Thus a miner succeeded when he was injured after illegally hitching a lift underground. However, the claimant must still show that he was continuing to act for, or in connection with, his employer's business. The difficult question to be asked is 'ignoring the prohibition, was the claimant doing his job?' Because of this the claim failed when a dock worker was injured moving an obstacle with a fork lift truck which had been left unattended by its driver. ${ }^{62}$ This decision has been considered harsh and has been distinguished from other cases on the basis that the prohibition against the unauthorised driving had been strictly enforced, and only this justified the refusal of benefit. ${ }^{63}$

\section{B. Compensation trigger}

There are two routes only to obtaining benefit. The claimant must show that his injury is either the result of an 'accident' or a 'prescribed disease'. Traditionally accidents have been much more likely to be the basis for a claim. However, the nature of work has changed: when the industrial scheme was introduced in 1948 almost two thirds of jobs were in heavy industry whereas today $70 \%$ of employees work in office and service industries. As a result, accidents are less common. However, with increasing scientific recognition of the effects of work upon health, diseases have become much more important so that there are now as many claims for diseases as there are for accidents. ${ }^{64}$ This is in stark contrast to the tort system where there are five times as many claims founded upon accident

61 Social Security Contributions and Benefits Act $1992 \mathrm{~s} 98$.

$62 \mathrm{R} v$ Deputy Industrial Injuries Commissioner, ex parte Bresnahan [1966] 1 Lloyd's Law Reports (Ll Rep) 69.

$63 \mathrm{R}(\mathrm{I}) 1 / 70$.

64 Department for Work and Pensions, Industrial Injuries Benefit Quarterly Statistics, table 1.5. These cover the period to December 2009. Allowance is made for the exceptional increase in disease claims following the prescription of new conditions. <http:// research.dwp.gov.uk/asd/asd1/iidb/index.php?page=iidb_quarterly_dec09>. 
as opposed to disease. 65 The traditional preference for traumatically caused disability by accident reflects the mistaken assumption that accidents are man-made whereas diseases are natural hazards. ${ }^{66}$ Ironically there is empirical evidence that it is the victims of disease rather than accident who are more likely to have serious medical needs and be left with a residual incapacity. ${ }^{67}$

46 At first sight there seem to be separate legal provisions dealing with each of the two forms of injury. However, as explained below, the dividing line is often unclear, and the scope of an 'accident' is not as limited as it may appear. Because of this, there are diseases which can be considered to result from an accident. In addition, for historical reasons, the meaning of accident has been strained so that, unexpectedly, it includes not only diseases but also other conditions which give rise to entitlement to compensation.

47 The 'prescribed diseases' can only be compensated if they appear on a legislative list. By contrast, accidents are open-ended and not confined by the words of a statute. An advantage of claiming for a prescribed disease is that there are statutory presumptions which can help satisfy the requirement to prove a work connection. There are no such presumptions to assist claimants in the case of accidents.

\section{Accidents}

48 Although an accident has been defined as 'any untoward event which is not expected or designed', ${ }^{68}$ it is clear that an event need not be unforeseeable or exceptional in order for benefit to be paid. The claimant does not have to show that the strain which caused his back injury was unusual for the job or that it was an entirely unexpected risk. ${ }^{69}$ It is the result that must be unintentional not the act itself. Thus the farm labourer who deliberately handled frozen material throughout the day and then found that he had suffered frostbite was able to claim. ${ }^{70}$ Acts intended by other people to inflict injury are also covered by the scheme even though they are deliberate. For example, a schoolteacher who was beaten up by his

\footnotetext{
65 See no 115 below.

66 J Stapleton, Disease and the Compensation Debate (1986).

67 D Harris et al, Compensation and Support for Illness and Injury (1984).

68 Fenton $v$ Thorley [1903] Appeal Cases (AC) 443.

69 CI $5 / 49$.

70 CI $126 / 49$.
} 
pupils was found to have suffered injury by accident. ${ }^{71}$ Unlike the wording in many private insurance policies, the scheme does not require that an accident result from an event external to the claimant's body. It can therefore include an internal physiological change for the worse, such as a muscle strain or rupture.

Accidents must be distinguished from, firstly, diseases compensated under the prescribed list system described below and, secondly, conditions which, although developing as a result of a work process, cannot be attributed to an accident. This last distinction refers to a situation where, because of his work, the claimant's condition becomes worse over a period of time and it may not be possible to identify any precise moment when physical deterioration occurs. An accident cannot then be found. Instead the wear and tear is the result of 'process' and, as such, is outside the scheme unless it constitutes a condition covered by the list of prescribed diseases. For example, injury to a hand caused by a pneumatic drill could be held to be neither an accident nor a prescribed disease. ${ }^{72}$ Although this distinction between accident and process is crucial, it can be a difficult one to draw and it depends on the facts of each case. Three factors are relevant:

- Continuity - Does the injury result from continuous day to day exposure? If so, it is more likely to be process and outside the scheme, as where there was continuous exposure to dust over twenty years. ${ }^{73}$

- Length of time - The longer the exposure needed to produce injury, the more likely it is to be held the result of process and outside the scheme. The claimant was therefore denied compensation where his injury was the result of exposure to various chemicals over a period of eighteen years. ${ }^{74}$ By contrast, an injury resulting from only three days spent stitching leather was held to be the result of accident. ${ }^{75}$

- Particular event causing injury - If the claimant can point to a particular event at a precise point in time which caused injury, it is more likely to be considered an accident. The claimant could not do this and benefit was not payable where he suffered from a nervous disorder caused by general uncongenial working conditions. ${ }^{76}$ This contrasts with another case where the claim succeeded because each repeated explosion at the

71 Trim School v Kelly [1914] AC 667.

72 However, in 1996 carpal tunnel syndrome was listed as a prescribed disease for those using hand held power tools.

73 Roberts v Dorothea Slate Quarries Ltd [1948] 2 All ER 201.

$74 \quad \mathrm{R}(\mathrm{I}) 7 / 66$.

75 R(I) $43 / 61$.

76 Fraser $v$ Secretary of State for Social Services [1986] Scots Law Times (SLT) 386. 
workplace was held to be an accident, and it was a series of these accidents which gave rise to the claimant's neurosis. ${ }^{77}$

50 There are two arguments, in particular, which may be made by claimants in order to establish injury by accident. They illustrate the strain that has been put on the word, and the difficult and often artificial distinctions which have to be made:

- The first argument is that injury can result from a series of accidents rather than a process. This enabled the claim to succeed where a hernia was caused by the continual operation of a stiff lever, each movement leading to a minute widening of a tear in the muscle wall and each amounting to an accident. ${ }^{78}$

- The second argument is that injury has resulted from one accident which occurred during a process which may have worn down the body's defences. This accident can simply be the final event - such as the breakthrough by which infection penetrates the skin. Even the onset of disease can then be an accident, as where a stray germ of anthrax entered the body via the eye. ${ }^{79}$ Infective skin conditions are often regarded as having developed by accident. Similarly, if a harmful process culminates at a point where a physiological change for the worse occurs, a claim may succeed. This happened where pressure on a nerve from a buckle on a knee over a period of ten weeks culminated in paralysis of the leg. ${ }^{80}$ This argument blurs the distinctions between accidents, diseases, and processes, with the result that the law can be extremely difficult to apply.

\section{Disease ${ }^{81}$}

51 As described immediately above, it may sometimes be possible for injury by disease to be classified as an accident. However, this route cannot be taken if the disease is on the prescribed list specified by statute as directly falling within the scheme. ${ }^{82}$ Then the conditions set down by the list must be satisfied. The list contains not only diseases readily recognisable as such

$77 \quad \mathrm{R}(\mathrm{I}) 43 / 55$.

$78 \quad \mathrm{R}(\mathrm{I}) 77 / 51$.

79 Brintons $v$ Turvey [1905] AC 230.

80 R(I) $18 / 54$.

81 N Wikeley, Compensation for Industrial Disease (1993); R Lewis, Compensation for Occupational Disease (1983) 5 Journal of Social Welfare Law 10.

82 The list is contained in the Social Security (Industrial Injuries) (Prescribed Diseases) Regulations 1985 SI No 967. 
(for example, pneumoconiosis and certain forms of cancer) but also conditions which may result from certain types of work processes (for example, occupational deafness and cramp of the hand). The list is definitive of the diseases or conditions that may be compensated in the sense that if they are not on the list and are not the result of accident, no claim can be made for them even if they can be shown to have a work connection.

The statutory list, begun in 1906, now runs to 72 diseases or conditions. It is divided into four sections according to whether the cause is a physical, biological, chemical or other agent. If the disease is on the list, there is usually a statutory presumption to help establish the work connection. However, the presumption does not apply if the disease is listed for an occupation where proof in the individual case is specifically required.

The list imposes five different types of conditions which limit the scope of potential claims by -

- The type of work done

- The minimum period of exposure to the risk

- The period of onset within which the disease must develop following exposure

- The minimum level of severity of the disease

- Whether or not the presumption applies that the disease has been caused by the occupation.

The list prescribes diseases only in relation to particular occupations where workers are thought to be especially at risk: in theory, the risk of contracting such a disease should not be common to all people. In addition, the legislation requires that the attribution to particular employments should be established or presumed with reasonable certainty. However, these stringent requirements have been relaxed a little in recent years. For example, 'reasonable certainty' is now interpreted to mean that a disease may be prescribed as long as there is proof only on a balance of probability that there is a work connection. ${ }^{83}$ In addition, some afflictions common in the population at large have now been listed, such as deafness which was prescribed in 1975 although only in relation to very particular occupations. Similarly, bronchitis was added to the list in 1993, but was confined only to those who were coalminers. In spite of such evidence of a more liberal approach, in general it remains the case that there is reluctance to prescribe

83 Social Security Contributions and Benefits Act 1992 s108 as interpreted by the Industrial Injuries Advisory Council (IIAC) in its Periodic Report (1993). 
illnesses which are common in the population at large, especially arthritic conditions, upper limb disorders, stress ${ }^{84}$ and mental illnesses. As a result, overall, the recipients of benefit for prescribed diseases represent only the tip of the iceberg of occupational ill-health generally.

55 Occasionally the conditions laid down by the job descriptions are easily satisfied. For example, tuberculosis is prescribed very broadly for 'any occupation involving contact with a source of tuberculosis infection.' However, at other times the conditions are much more detailed and stringent, as where vibration white finger is prescribed for a list of very specific occupations. For example it is prescribed where there is 'holding of material being worked upon by pounding machines in shoe manufacture.' Time limits may also be imposed: for occupational deafness the claimant must have worked in the prescribed occupation for at least ten years, and must make the claim within five years of leaving it; for chronic bronchitis and emphysema the period for work is twenty years in a coal mine.

56 The list system has been gradually extended since it was first devised over a hundred years ago. However, the process of adding new diseases and occupations has been very slow. For example, it took thirty years from first investigation of vibration white finger before entitlement to compensation arose. Nor is prescription retrospective in its effect. The Recommendation of the European Commission that Member States adopt the European schedule of occupational diseases ${ }^{85}$ has not been supported. ${ }^{86}$

57 A fundamental objection to the system is that, if the disease is not on the list and an accident cannot be established, then no benefit can be claimed no matter how clear the work connection. Thirty years ago it was proposed that for diseases not on the list the claimant should be allowed to produce evidence to show that work was the cause of the disablement in his individual case. ${ }^{87}$ However, this proposal has never been enacted. More recently it has been noted that there is little evidence of the scale of the problem, and that it can be alleviated by including individual proof as a possibility when new diseases are listed. ${ }^{88}$ For example, when occupational asthma was listed as being caused by various agents, a further

84 Industrial Injuries Advisory Council, Stress at Work as a Prescribed Disease and PostTraumatic Stress Disorder (2004) Position Paper No 13.

85 90/326/EEC, Official Journal (OJ) L 160, 26.6.1990, 39-48.

86 Industrial Injuries Advisory Council, European Commission Recommendation - Occupational Diseases (1992) Position Paper No 8.

87 Industrial Injuries Advisory Council, Industrial Diseases: A Review of the Schedule and the Question of Individual Proof (1981, Cmnd 8393).

88 Industrial Injuries Advisory Council, Coverage under the Industrial Injuries Scheme for Injury by 'Process' (1995) Position No 9. 
general category was added which allowed recovery for 'any other sensitising agent inhaled at work.'

Whereas about 200,000 people presently receive disablement benefit because they have suffered an accident, about 58,000 do so because they have a prescribed disease. This reflects the historical importance of accidents, but does not indicate how disease has increased in significance in recent years. There are now as many new claims made based upon disease as there are for accidents with over a thousand made each month. Deafness, vibration white finger and pneumoconiosis account for half of the prescribed disease pensions which are presently in payment and generally reflect exposure to risk factors some years ago. Of new awards, diseases associated with asbestos now account for about $15 \%$ of the total, about the same as for each of the other three main diseases.

There are four questions to be determined in a prescribed disease claim:

- The diagnosis question - is the claimant suffering from a prescribed disease?

- The disablement question - has the disease resulted in the claimant suffering a loss of faculty?

- The employment question - has the claimant been employed in an occupation listed in relation to the disease? Although it is not necessary for the claimant to have worked exclusively in one of the processes listed, the involvement should be more than merely trivial so that, in one case, two days in seven years work was insufficient. 89

- The causation question - is the disease due to the claimant's occupation? Here in many cases the claimant can be helped by a statutory presumption: if he has worked in a relevant occupation in the month preceding the development of the disease, it is presumed that the disease is due to the nature of the employment unless the contrary is proven.

\section{Scope of protection}

\section{Personal injury}

The legislation specifies that 'personal injury' must be suffered. Although $\mathbf{6 0}$ this can include a relatively trivial harm, in most cases the scheme requires disablement to be assessed as at least $14 \%$ in order for benefit to be paid.

$89 \mathrm{R}(\mathrm{I}) \mathrm{8} / 57$. 
In effect, this means that the claimant must suffer the equivalent of the loss of an index finger in order to recover any benefit.

61 Injury is usually all too apparent. However, where the effect is less clear, the claimant must show that he has suffered some physiological or psychological change for the worse. He cannot simply rely upon an increase in pain to found entitlement. For example, although an internal injury such as a muscle pull or a rupture may be sufficient, if the claimant is already suffering from disc trouble and experiences an increase in back pain whilst lifting at work, he must show that there is a physical deterioration in the disc condition itself. 90 The increase in pain alone will not suffice.

\section{Mental injury}

62 Personal injury includes injury to the mind as well as the body. However, stress related illnesses are not included on the list of prescribed diseases under the industrial scheme, and very few of them result in any form of compensation. In spite of the very widespread nature of mental illness and stress and the recognition that much of it is associated with work, there is little acknowledgement of this in the industrial scheme. It is clearly possible for a claim to succeed if a mental condition follows on from an accident at work which causes physical injury. ${ }^{91}$ In theory, even if the claimant does not suffer physically he may claim for a mental condition alone if it is the result of an accident caused by his job. On this basis, for example, benefit was paid where the claimant developed a neurosis after witnessing the death of another employee at work. ${ }^{92}$ However, in such a case the claimant must establish not only that there has been a specific disturbing event, but also that it constitutes an accident and is the cause of his condition. Because of this, it was doubted whether a fire officer could recover when he suffered a post-traumatic stress disorder as a result of attending a series of horrific fatal crashes unless he could identify the precise incidents which had specifically caused his mental state. ${ }^{93}$ It is not therefore surprising that most employees suffering the usual stress related illnesses find it almost impossible to claim.

$90 \mathrm{R}(\mathrm{I}) 1 / 76$.

91 CI $4 / 49$.

$92 \mathrm{R}(\mathrm{I})$ 49/52.

93 Chief Adjudication Officer v Faulds [2000] 2 All ER 961. 


\section{Other than personal injury}

The industrial scheme offers no compensation for damage to workers' 63 property or for pure economic loss. Nor does it cover dignitary injuries resulting from discrimination or sexual harassment. Scope for such claims lies outside of the industrial injuries scheme and is to be found especially in general employment and anti-discrimination legislation. ${ }^{94}$

\section{Heads and levels of benefit}

The industrial scheme offers monetary compensation only. Medical care and rehabilitation assistance are available free of charge under the National Health Service, but no special provision is made for those injured at work. Nor is the scheme linked to any retraining or support services to encourage a return to work. About $£ 893$ million is spent on industrial injuries benefit being about $0.5 \%$ of total benefit expenditure. ${ }^{95}$ This represents a fall of about $12 \%$ from the level of twenty years ago when about $£ 984$ million was spent.

There are about 40,000 new claims made each year fairly evenly split 65 between prescribed diseases and accidents. ${ }^{96}$ Less than half of all these claims result in the payment of benefit, often because the minimum threshold of disablement is not reached. ${ }^{97}$ In 2009 there were 324,000 beneficiaries of payments under the industrial scheme, the great majority of them having first gained entitlement many years earlier, with many of them retaining entitlement to benefits which are no longer available to new claimants. As a result of the build up of pensions in the system, about two thirds of recipients are aged over 60 . There are four times as many men than women. Of new claimants, women account for only $30 \%$ of accident cases, and less than $10 \%$ of disease cases. On average, claimants are assessed as suffering only minor disablement and receive about $£ 48 \mathrm{a}$

94 Below nos 122-123.

95 Department for Work and Pensions, Benefit Expenditure Tables - Medium Term Forecast Table 1b for 2009-10. <http://statistics.dwp.gov.uk/asd/asd4/index.php?page=medium _ term $>$. The total benefit expenditure was $£ 155$ billion.

96 Department for Work and Pensions, Industrial Injuries Benefit Quarterly Statistics, table 1.5 up to December 2009 making allowance for a sharp increase for diseases when a new disease is prescribed. $<\mathrm{http}$ ://research.dwp.gov.uk/asd/asd1/iidb/index.php?page=iidb_ quarterly_dec09>.

97 No 60. 
week, ${ }^{98}$ this being about a tenth of the average weekly wage. ${ }^{99}$ The maximum award without any supplement in 2011 is $£ 150-30 p$, and is less than a third of the median wage.

66 The benefit is paid exclusively by means of a pension; lump sums of up to about $£ 4,000$ which used to be awarded for minor injuries were abolished in 1986. Pensions increase in line with inflation and are often paid for life even though that period is uncertain. As a result their capital value can be high, ${ }^{100}$ although the pension cannot be commuted into a lump sum. A pension can be increased later if there is an unforeseen aggravation of injury. In these respects the pension is more flexible and offers a more certain future for claimants than the once and for all lump sum traditionally awarded in tort. However, in serious injury cases the recent development of periodical payment orders for damages in tort offers greater flexibility. 101

67 Although twenty five years ago there were several different benefits available under the industrial scheme, today only disablement benefit remains. In effect, this is a payment only for non-pecuniary loss. It compensates for the effect of the work injury upon body or mind irrespective of whether it results in a reduction in earnings or in additional costs. The focus is upon injury only to person and not to pocket. There is one very limited exception to this: in cases of the most severe injury, affecting only one in a hundred recipients of disablement benefit, two supplements can be claimed to meet the need for care and attendance.

68 It is very important to emphasise that loss of earnings resulting from the industrial injury is not covered by the scheme. Reduced earnings allowance which used to compensate for this was abolished in 1990 (although 120,000 old pensions remain in payment and new entitlement for old exposure can still arise). The allowance used to account for $40 \%$ of the expenditure upon the industrial scheme. It was withdrawn because of its extreme complexity and the high cost of determining the precise reduction in earnings. This was in spite of a maximum award being set which, in practice, prevented $90 \%$ of claimants from obtaining their full loss. By contrast, in other European countries most of the benefits that are paid under workers' compensation schemes are for loss of earnings.

\footnotetext{
98 Department for Work and Pensions, Industrial Injuries Benefit Quarterly Statistics, table 1.2: <http://research.dwp.gov.uk/asd/asd1/iidb/index.php?page=iidb_quarterly_dec10>.

99 Office for National Statistics, Labour Market Statistics <http://www.statistics.gov.uk/ pdfdir/lmsuk0910.pdf $>$.

100 No 76.

101 Nos 126-127.
} 
Industrial death benefit which offered a very small preferential payment to surviving spouses is another benefit which has been abolished. Since 1988 there have been no benefits payable to dependants under the scheme. The costs of private medical treatment or rehabilitation have never been recoverable under the scheme. Overall, therefore, no compensation is available for any pecuniary losses caused by the injury. Industrial deaths continue to decline and remain among the lowest in Europe.102 Although the industrial scheme now offers only disablement benefit, it must be remembered that the claimant remains entitled to other benefits available under the social security scheme irrespective of where injury occurred or how disability was caused. In particular, for short term absence from work claimants can obtain statutory sick pay (currently only $£ 81$ a week) and thereafter, in the longer term, employment and support allowance (up to $£ 100$ a week). There are also disability living allowances with additions to cover the need for mobility (up to $£ 51$ a week) and the need for care (up to $£ 73$ a week). There are also means tested tax credits for those partially incapacitated. Apart from general social security provision, most claimants will also benefit from sickness or disability monies available from their employer under their contract of employment. The level of provision here varies according to the employment, with the working class receiving the lowest payments. In many schemes the employee may receive the full wage loss but the duration of the payment will depend upon the particular work done. The range of welfare and other support available to injured people was considered in an earlier book in this series. ${ }^{103}$ In spite of this additional provision, the UK spends a lower proportion of its Gross Domestic Product on sickness, invalidity and occupational benefits than other European countries. ${ }^{104}$ This is partly offset by claimants also being allowed to sue in tort for their work injuries.

\section{Assessment}

To gain entitlement to the industrial benefit it is not necessary to show that the resulting disablement is permanent, but it must continue for at least fifteen weeks because entitlement usually does not arise until that

\footnotetext{
102 Health and Safety Executive, Statistics on Fatal Injuries in the Workplace 2010-11 $<$ http://www.hse.gov.uk/statistics/fatalinjuries.htm>.

103 Magnus (fn 18).

104 Eurostat, Social Protection Expenditure and Receipts 1990-1998 (2000, European Commission).
} 
length of time has passed since the accident or onset of the disease. Entitlement may then continue for as long as the disablement lasts. Payments can therefore endure through incapacity, unemployment and retirement, and end only on death. As a result, as discussed below, the pension can be very valuable if assessed in capital terms.

71 The extent of disablement is assessed with the help of medical authorities. It is expressed as a percentage with the maximum basic award being the pension which statute prescribes as payable for $100 \%$ disablement. Percentages are rounded up or down to the nearest multiple of ten. The assessment is made by comparing the claimant to a person of the same age and sex who is of normal health. This assessment is therefore an objective one which ignores the claimant's own personal or social circumstances, and no attempt is made to compare the claimant's condition before and after the injury. Instead, the comparison is with a 'normal' person. In theory, this is very different from the much more subjective assessment which takes place in tort, although, in practice, the tort award is much more divorced from the individual than textbooks would lead us to suppose.

72 In arriving at their assessment the authorities are assisted by a crude statutory table. This deals almost entirely with anatomical losses and not the less visible injuries such as internal ones. In tort there are much more sophisticated non-statutory guidelines to assist assessment. ${ }^{105}$ By contrast the industrial injuries table indicates, for example, that loss of a thumb is assessed as $30 \%$ disablement; loss of an eye is assessed as $40 \%$ disablement; and amputation below the knee with a stump exceeding 9 centimetres but not exceeding 13 centimetres is assessed as $50 \%$ disablement. However, these figures are not set in stone: the percentages can be varied if they do not provide reasonable assessments of the degree of disablement. The great majority of claimants suffer only minor injury. About two thirds are assessed at less than $24 \%$ disabled, and this is then rounded so that by far the most common pension is that payable for $20 \%$ disablement. ${ }^{106}$

73 The table can be criticised on several grounds. It pays too little attention to the functional effects of disablement: what does the disability prevent the claimant from doing? It offers little help with non-anatomical injuries so that low back pain, for example, is notoriously difficult to assess. The

105 Judicial Studies Board, Guidelines for the Assessment of Damages in Personal Injury Cases (10th edn 2010).

106 The average payment, taking into account the minority of substantially higher awards, is $£ 48$ a week and is equivalent to a pension slightly more than that payable for $30 \%$ disablement. 
table is also biased in favour of minor injury and under-compensates severe disablement. A counterweight to this criticism is the important provision in the legislation which excludes lesser injuries from the scheme. Except in cases of certain industrial diseases such as pneumoconiosis, no entitlement to benefit arises unless the claimant is assessed as at least $14 \%$ disabled. This is the equivalent to the loss of an index finger. Any other finger can be lost in an industrial accident and it will give rise to no entitlement to benefit.

\section{Rate of payment}

The rate of the pension is directly proportionate to the percentage of disablement assessed. In 2011 the maximum payment for $100 \%$ disablement is $£ 150$ a week so that a $50 \%$ assessment - equivalent to the loss of all four fingers on one hand - results in a pension of $£ 75$. However, as with many other compensation schemes, the payments disproportionately relate to minor injuries with the average pension being only $£ 48$ a week.

By contrast, in cases of the most severe injury two further supplements to disablement benefit may be paid. These are constant attendance allowance and exceptionally severe disablement allowance. However, only about $1 \%$ of pensioners receive these supplements because entitlement depends upon establishing at least $95 \%$ disablement. Although constant attendance allowance can increase the disablement pension by up to $£ 120 \mathrm{a}$ week, the real benefit to the industrially injured is in fact much lower. This is because there is another attendance allowance benefit available under the main social security scheme and this provides up to $£ 73$ a week and it is not available to those who receive the industrial allowance. The weekly preference given to those injured at work is thus about $£ 47$. About a third of those who receive constant attendance allowance may also gain entitlement to exceptionally severe disablement allowance if they can show that the need for such attendance is likely to be permanent. A further increase of $£ 60$ a week is then payable to very small numbers of people. Again benefits under the main scheme may reduce the overall value of the industrial preference. Recommendations that these two supplements should be abolished so as to leave industrial injury victims reliant upon the provision made in the main social security scheme have not been enacted. 


\section{Comparison of the industrial injuries pension with damages in tort}

76 The value of an industrial injuries pension can be high if assessed in capital terms. This is particularly so because it can last for life and it is protected against inflation. In addition, it is tax free and generally does not lead to a reduction of other contributory benefits also being received under the main social security scheme. As a result the capitalised value of the pension can often compare very favourably with the lump sum awarded in tort, at least if attention is confined to the lesser injury cases.

77 By contrast, the income arising from the lump sum awarded in tort is taxed, and it has been found difficult to protect many claimants from the ravages of inflation. The assessment in tort is based upon achieving a rate of return from investment which, in practice, is impossible to obtain. The lump sum paid is invariably the result of a compromised deal out of court. Because of the uncertainties involved in litigation, this deal is likely to involve an agreement to accept significantly less than the sum which the strict rules applied by courts would allow. However, when it comes to catastrophic injury the industrial scheme cannot begin to match the multi-million pound awards or guaranteed pensions of tens of thousands of pounds available in the tort system. This is because the scheme offers nothing for care costs or for loss of earnings and pension entitlement, whereas these constitute the major elements of the damages awarded in tort where there is serious injury.

78 To illustrate the potential value of disablement benefit let us take the case of a typical recipient who has an assessment of close to the average awarded of $30 \%$. This could be awarded for the loss of an eye. The resulting pension is then $£ 45$ a week amounting to $£ 2,344$ a year. If this were being received at the young age of 21 , the lifetime capitalised value of the pension would be $£ 74,724 . .^{107}$ Even if the claimant were aged 60, the capital value of the pension would still be $£ 42,946$. By contrast the nonpecuniary valuation in tort for the loss of an eye is between $£ 36,000$ and $£ 43,000 .{ }^{108}$ This comparison illustrates that, over the course of their lifetime, almost all workers suffering lesser injury obtain more for their nonpecuniary loss from the industrial injuries system than from tort. Under the industrial scheme the younger the worker the more valuable their

\footnotetext{
107 Government Actuary's Department, Actuarial Tables for Use in Personal Injury and Fatal Accident Cases (7th edn 2011) table 1 using a $2.5 \%$ discount rate for a loss for life for a man.

108 Judicial Studies Board (fn 105).
} 
total pension, whereas in tort age rarely affects the amount paid unless the claimant is very old. In making these comparisons it must be remembered that the industrial scheme, unlike tort, offers nothing for earnings lost or for care costs incurred.

Let us take the comparison further by examining what would happen in

the case of the most catastrophic injury, such as quadriplegia or severe brain damage. The maximum basic pension which could be awarded by the industrial scheme is $£ 150$ a week, equivalent to $£ 7,815$ a year. (This ignores the two supplements that are also payable partly because they have lesser equivalents under the main social security scheme). For a 21 year old the capitalised value of the basic pension is $£ 249,083$. For a 60 year old it is $£ 143,025$. These figures, derived from actuarial tables, are not far out of line with the prescribed amount of between $£ 212,000$ and $£ 265,000$ awarded in tort for the most severe injury. However, again we must remember that the tort system would also take into account the financial losses and care costs incurred. This means that invariably in such a case, especially if a high income earner is involved, the award in tort would run into millions of pounds, and the difference with the industrial scheme would then be very apparent.

\section{E. Funding systems}

In 1948 the old system of privately financed workmen's compensation gave way to the state-run industrial injuries scheme. Private insurance was replaced by public funding. A separate fund was created to pay for the new scheme. This was financed by compulsory contributions per employee; the parties could not choose to self-insure and opt out of the system. The initial proportion levied was $40 \%$ each from both the employer and employee, with the remaining $20 \%$ being contributed by the Exchequer from the general taxes it received. The set contributions did not distinguish between industries on the basis of their relative risk of causing injury: such rating was rejected as being unduly expensive to administer and contributing little to industrial safety. ${ }^{109}$ As discussed above, employees were covered from their first day at work; there was no requirement that they contribute a minimum number of contributions in order to be

109 The Pearson Report (fn 12) vol 1 para 902. Similar conclusions are reached in K Armstrong/D Tess, Fault versus No Fault for Personal Injury - Reviewing the International Evidence (2008) paper presented at the Institute of Actuaries, Australia. 
eligible for the benefits. The scheme thus had only a loose connection with the insurance principle.

81 The funding system remained in place for over 25 years, although the contribution proportions changed so that eventually employers were funding $57 \%$, employees $26 \%$ and the Exchequer $17 \% .110$ Gradually the administration of the scheme was integrated within the general structure of social security. In 1973 this culminated in the abolition of the separate fund for industrial injuries. ${ }^{111}$ In part this was because of the general dislike of earmarked contributions and the difficulty and expense of working them out. In 1990 funding for the scheme was transferred to the Consolidated Fund so that the scheme is now wholly tax supported. This means that there is now no separately earmarked fund nor are there contributions which directly support industrial injuries compensation.

\section{F. Administration and adjudication of claims}

\section{Claims and appeals}

82 The industrial injuries scheme, being part of general social security provision, is administered by the Department for Work and Pensions (DWP). Claims are made to the DWP and a lay decision maker determines the claim without a hearing on the basis of all the evidence on paper, including advice that may be sought from doctors who have been especially trained in disability analysis. Adjudication in industrial injury claims is usually more complicated than in other social security cases, often because of the medical questions that may have to be resolved. Claimants are more likely to challenge the decision with the result that there were 7,300 appeals in 2009-10 from the 40,000 claims for benefit. ${ }^{112}$

83 Disputes take place outside the court structure for civil justice in general. Instead there is a right of appeal against the DWP decision to a First-tier Tribunal. This tribunal consists of a legally qualified judge who may sit alone or with up to two other people who have either financial, medical or disability expertise. A further appeal then lies to the Upper Tribunal and beyond, if permission is obtained, to the Court of Appeal.

110 Brown (fn 25) 84.

111 Social Security Act 1973 s 94.

112 Ministry of Justice, Tribunals Service Quarterly Statistics 2009-10, table 1.1c <http://www. tribunals.gov.uk/Tribunals/Documents/Publications/tribs-q42009-10-statsc.pdf $>$. 


\section{Tribunals not courts}

Tribunals are very different from those traditional courts which determined workmen's compensation cases before the system was nationalised in 1948 . 'In no time at all workmen's compensation descended from its lofty ideals of being a no-fault social service into a squalid legal battlefield between trade unions and insurance companies, with lying, cheating, and chicanery on all sides and astronomical expenditure on administrative, legal and medical costs. ${ }^{113}$ It may be argued that tort claims today share many of these features. By contrast the tribunal system offers a cheap, speedy and more informal system of justice, and the involvement of lawyers is much less common. ${ }^{114}$ The tribunal judge takes a more active part in proceedings than a judge in the traditional civil court. The procedure is much less formal and witnesses are rarely called. The process of appeal typically takes from three to eight months, and the hearing lasts usually less than an hour. Claimants do not have to attend, although most do. This is partly because, in work accident cases, the majority are assisted by a lawyer or representative appointed by their trade union, although there is no legal aid available to pay for the cost. The tribunal service itself is free.

\section{Administrative cost}

In 2007 the administrative cost of paying disablement benefit was said to

be only $2 \%$ of the total cost of the scheme. ${ }^{115}$ In contrast, fourteen years earlier the cost was said to be $11 \%$ of the benefit expenditure. ${ }^{116}$ Whatever the exact figure, it sharply contrasts with that for the tort system which consumes in operating costs $45 \%$ of the total of damages paid and administrative expenditure. That is, for each pound spent on the tort system only 55 pence goes to the claimant. 117 Whereas the administrative cost of the tort system is almost as much as the damages it pays out, the industrial injuries scheme is much more cost effective partly because it is based on

113 OH Parsons, A No-Fault System? Not Proven (1974) Industrial LJ 129.

$114 \mathrm{~J}$ Baldwin/N Wikeley/R Young, Judging Social Security (1992).

115 Department for Work and Pensions, The Industrial Injuries Disablement Benefit Scheme a Consultation Paper (2007) 4.19. The costs nevertheless are about $20 \%$ of the cost of new claims.

116 Industrial Injuries Advisory Council, Periodic Report (1993) 28.

117 The Pearson Report (fn 12) vol 1 para 256. The Lord Chancellor's Civil Justice Review $(\mathrm{Cm} \mathrm{394,1986)}$ estimated that the cost of the tort system consumed 50 to $70 \%$ of the total compensation awarded in personal injury cases. See no 138 below. 
no-fault, involves few lawyers, and uses the tribunal system rather than the traditional court structure.

\section{G. Right of recourse of workers' compensation institutions}

\section{Rights of recourse against the employer}

86 The industrial injuries scheme is financed by the state. Workers' compensation institutions as exist in other European countries are unknown in the UK and no rights of recourse therefore directly arise. Because these workers' compensation institutions elsewhere in Europe provide collateral benefits to the injured, they are allowed subrogation rights to recover their payments from tortfeasors. They enforce these rights via bulk recovery arrangements whereby liability insurers agree in advance to reimburse a percentage of all claims under a certain amount. This avoids litigating individual cases and makes subrogation administratively workable and financially efficient. 118

87 Bulk recovery agreements in favour of the state in respect of social security benefits do not exist in the UK because there is a comprehensive benefit recovery system in place as described below. ${ }^{119}$ The state is able to reclaim the social security benefits paid to a claimant in respect of an injury for which damages in tort are also paid. Unlike in other countries, each individual claim for personal injury is examined to determine whether benefit can be recovered from the compensator on the facts of the case. In the great majority of cases the compensator is the liability insurer of the employer although a few large employers and state organisations are allowed to self-insure and pay damages directly themselves. However, if no tort claim is brought, benefits cannot be recovered even though it may appear that an employer was responsible for the injury. The state has no independent right of recourse against a tortfeasor; its reimbursement is parasitic upon the tort claim.

118 W Pfenningstorf/D Gifford, A Comparative Study of Liability Law and Compensation in Ten Countries and the USA (1991) 134.

119 Nos 142-149 below. 


\section{Rights of recourse against a co-worker or third party}

In theory, the state's claim for reimbursement against the compensator

could include a claim against a co-worker who negligently caused the injury and personally paid the damages. However, in practice this never happens, and no recourse arises. Even though the basis of many tort claims rests upon the principle of vicarious liability, in practice the negligent co-worker causing the injury never actually pays the damages himself. It is always the responsibility of the employer or his insurer. There is even an agreement between insurers and the employers' organisation that insurers will not subrogate and seek to recover the damages they have to pay from the negligent employee. ${ }^{120}$

A similar position arises in relation to reimbursement from third parties. In theory, for example, it is possible that a negligent manufacturer could be liable for an injury at work resulting from the supply of defective equipment. However, the law makes the employer strictly liable in such a case with the result that, in practice, the employer would always be the party to be sued, although he might seek to join the manufacturer to the action. Again, therefore, the state is unable to seek reimbursement from any third party unless it actually pays damages directly to the claimant.

\section{H. Interaction with general social welfare provision and private insurance}

\section{The sources of funding}

The funds of first (and often last) resort are those provided by the state. 90 That is, the claimant usually will first seek social security benefit and free medical care from the National Health Service. It is also possible for a minority of claimants to benefit from various forms of private insurance. These include accident and disability insurance, permanent health insurance, and private medical insurance. More important for the victim of an industrial injury are the benefits usually provided by his employer. These include statutory sick pay, a low amount specified by legislation and currently $£ 81$ a week. In contrast occupational sick pay may cover the greater part or even all of any wage loss for a set period in accordance with the terms and conditions of employment. That is, the injured worker's right to continue to receive wages will depend upon the terms negotiated

120 No 140 below. 
as part of the contract of employment. Some jobs may offer protection for many months absence from work and may replace in full the earnings that otherwise would be lost; other occupations will offer only limited repayment by allowing only a percentage of income to be recovered for a shorter period of time. In practice, the most generous protection is more commonly found as a part of the terms and conditions of work for those in middle class jobs, and there is much less support given to those in working class or manual jobs.

\section{Deductibility of benefits}

\section{a) Within social security}

91 There are general provisions within social security law which are aimed at preventing over-compensation for the same contingency or need. The rules are complex and inconsistent. ${ }^{121}$ However, in general it can be said that the receipt of industrial injuries disablement benefit has a limited effect on other benefits received. Claimants can often retain their entitlement to contributory benefits in addition to their industrial pension. For example, it does not affect the receipt of incapacity benefit or a retirement pension. Nor is the benefit taxable so that it does not affect receipt of working or child tax credits. Overall this establishes the basis for the industrial preference which, as discussed above, can be very valuable in certain cases.

92 However, disablement benefit will result in the reduction or loss of certain means tested income-related benefits. These include income support, pension credit, housing benefit, and council tax benefit. Even though disablement benefit is not paid because of loss of income, it is taken into account in this way and may result in an injured worker being worse off than if a claim had not been made. Disablement benefit can also affect how much war pension is paid. Finally, receipt of industrial injury constant attendance allowance prevents there being entitlement to attendance allowance or disability living allowance under the main national insurance scheme.

\section{b) Other than social security}

93 There is no question of disablement benefit being taken into account to reduce the compensation which the claimant or his employer may have arranged via a private insurance scheme. Nor will any occupational pay- 
ments for sickness or disability be affected. Private arrangements or benevolence are to be left out of account. Nor can any employer or private insurer claim from the industrial injuries fund any reimbursement of the benefits it provides. However, the disablement benefit paid can be recovered by the state from the compensator if there is a successful claim for damages in tort as explained next.

\section{Interaction with employers' liability}

The claimant in the UK is allowed not only to claim industrial injury benefit under the social security scheme, but also to sue the employer in tort. There is no employer privilege which exempts the employer from liability. The two types of claim are entirely separate so that there is no question of the social security claim being brought in the same proceedings as the tort claim. The compensation is sought from different funds, the one public and the other private, and they involve very different procedures, personnel and adjudication. A notable difference is that only about $1 \%$ of all tort claims are determined by a judge, the rest being settled out of court for a compromised sum. By contrast all benefit claims are determined and never compromised.

Before 1948 claimants were faced with a difficult choice: they could either obtain industrial benefit or damages in tort. They could not do both. For a variety of reasons claimants overwhelmingly opted for, or were pressed into receiving, the no-fault social security benefit. ${ }^{122}$ This left the tort system to play only a very limited role in the industrial field. ${ }^{123}$ There was judicial criticism of the 'deplorable' and 'extremely shabby' tactics used by insurers to prevent tort claims from being pursued.124 Eventually the employer privilege was abolished by statute, 125 and in the last sixty years or so tort claims for work accidents have flourished.

Until 1990 the state had no right to recover any of the social security benefits it paid to a claimant who later succeeded in a tort action. Legislation then set up the Compensation Recovery Unit able to claw back most of the benefits paid by the state to accident victims up to the date of the settlement of their damages claims. This scheme is described in more detail below. ${ }^{126}$

\footnotetext{
122 WA Dinsdale, History of Accident Insurance in Great Britain (1954) 161.

123 Bartrip (fn 11) ch 10.

124 Deane $v$ H F Edwards \& Co (1941) 34 Butterworth's Workmen's Compensation Cases (BWCC) 183.

125 Law Reform (Personal Injuries) Act 1948.

126 Nos 141-149 below.
} 


\section{Employers' Liability}

\section{A. Classification}

97 The liability of employers to employees for personal injury has traditionally been seen as lying within the law of tort. Although an action in contract is theoretically possible, it is rarely pleaded because in virtually all cases there would be no difference in result. The rules that are applied are part of the general civil law of obligations, although special provision has also been made at times for work accidents alone. One example of this is where statute provides that employers must insure against their liability.

98 Liability founded upon breach of statutory duty is the most important example of where, in effect, special provision has been made. Although the broad principles of such liability derive from the general law of tort, in practice the litigation is dominated by employers' liability claims: judges have held that violation of health and safety legislation will usually be enough, of itself, to found breach of duty in tort. By contrast, they have refused to allow road traffic legislation to be used to define the tort standard in the same way. As a result, the rules developed for breach of statutory duty have created a particular liability regime for work accidents. Notably this involves the imposition of what is often a stricter form of liability than that based upon proof of fault. In addition, for example, the defence of voluntary assumption of risk has been held inapplicable in a breach of statutory duty claim. The result, in practice, is that the basis of liability for work accidents is often very different from liability for other causes of injury.

\section{B. Elements of liability}

99 In broad terms, there are three bases for imposing liability upon an employer. In order of development, these are where the employer is liable -

- for the breach of duty by another employee who was acting in the course of employment (vicarious liability)

- for breach of a primary duty owed directly by the employer to the injured employee, the duty being placed on the employer by judges (breach of common law duty)

- for breach of a primary duty placed on the employer by Parliament (breach of statutory duty). 
The result is that liability is sometimes based upon fault (especially where 100 vicarious liability or breach of common law duty are involved), and sometimes it is strict (where statutory duty is involved). These different potential liabilities can be confusing. There is some uncertainty, for example, about the scope of strict liability. As a result, practitioners regard this area of law as more complicated than that involving road accident claims. ${ }^{127}$

\section{Vicarious liability}

Although originating in medieval times, vicarious liability was not relied 101 upon by an employee to sue his employer until the nineteenth century. The first reported case was in 1837 when an action against a butcher for the negligence of another employee in overloading his cart resulted in injury to the claimant. ${ }^{128}$ Liability was rejected because the claimant and the negligent employee were both employed by the butcher, and it was not thought appropriate for the law to intervene in the work relationship. This 'common employment' defence was very harsh and considerably restricted the use of vicarious liability. ${ }^{129}$

Later in the century both Parliament and the judiciary recognised the 102 severity of the law and tried to limit the effect of the defence of common employment. The Employers Liability Act 1880 prevented the defence from arising in a few situations. In addition, judges found that an employer could be liable for breach of his own duty of care owed directly to the claimant and involving no other employee. Vicarious liability and the defence to it was not then in issue. Finally, judges directly limited the scope of common employment by finding, for example, that it did not apply if a worker was injured when facing the same risks as those run by the general public. This was the case where a bus driver was injured when in collision with another bus. Partly because of these limitations the defence gradually fell into disuse and more claims based on vicarious liability then succeeded. However, common employment was not formally abolished until $1948 .{ }^{130}$ Even after that date, in practice, for a while only a few workers brought claims in tort. ${ }^{131}$

\footnotetext{
127 H Genn, Hard Bargaining: Out of Court Settlements in Personal Injury Actions (1987).

128 Priestley $v$ Fowler (1837) $3 \mathrm{M} \& \mathrm{~W} 1$.

129 RA Epstein, The Historical Origins and Economic Structure of Workers' Compensation Law (1982) 16 Georgia Law Review 775.

130 Law Reform (Personal Injuries) Act 1948 s 1 (1).

131 Bartrip (fn 11) ch 10.
} 
103 Vicarious liability requires that the fellow employee be held liable for causing the injury and this almost always involves proving that he was at fault. This is in sharp contrast with an action for breach of statutory duty where liability is often imposed irrespective of wrongdoing. Once fault is proven, vicarious liability requires that the injury be committed, firstly, by an employee as opposed to an independent contractor, and secondly, in the course of employment. Both of these requirements have already been discussed in relation to the industrial injuries benefit scheme, 132 and the lengthy examination of the course of employment is equally applicable here. There are only minor differences. For example, the special statutory provisions in relation to the course of employment under the industrial scheme are not replicated in tort law, although this has little effect in practice.

\section{a) Who is an employee?}

104 The old test of whether the employer was in control of the worker retains some importance, but today judges look at a much wider range of factors to determine the relationship. These include, for example, the method of payment, what financial risks are taken, who owns the tools or work equipment, what degree of responsibility was taken, and what rights there are to dismiss or to delegate the work. The description of the relationship in the contract is of relevance but cannot provide the definitive answer partly because the parties have incentives to disguise the true position. Overall, judges in recent years have made employers liable for a wider range of workers to reflect the increasing complexity of employment practices and structures. ${ }^{133}$

105 Although generally employers are not vicariously liable for the acts of independent contractors, they may be liable if they have breached a primary common law or statutory duty placed upon them. For example, although they are not vicariously liable for the fault of an electrical contractor causing an appliance to become dangerous, they will be strictly liable for breach of the statutory duties to ensure that tools and equipment are safe for workers to use. Employers may also be liable for breach of other 'non-delegable' duties although the scope of these is uncertain. ${ }^{134}$

\footnotetext{
132 Nos 19 and $28-40$ above.

133 R Kidner, Vicarious Liability: For Whom Should the Employer be Liable? (1995) 15 Legal Studies 47.

134 Rogers (fn 24) 20-21.
} 


\section{b) What is the course of employment?}

The cases here are as numerous as they are in relation to the industrial 106 injuries benefit scheme and for the same reasons: the difficulty at the margin of defining the limits of work. Again the decisions often must be read as confined to their specific facts. An act will be found to be within employment if it is expressly or impliedly authorised by the employer, or if it is sufficiently connected with the employment such that it can be said to be reasonably incidental to it. Many of the cases deal with issues already discussed such as those relating to travelling in the course of employment, or acting in an emergency, or establishing where the time and spatial limits of work are to be found. As under the industrial scheme, a more expansive view has been taken of the course of employment in recent years. In particular, it has been held that liability can arise if the act in question is so closely connected with the employment that it would be just to hold the employer liable.135 This vague test further expands potential liability.

\section{Breach of common law duty}

Partly as a means of evading the defence of common employment which 107 previously limited the scope for vicarious liability, judges imposed duties directly upon employers. There are four such duties. The employer must provide:

- competent staff

- adequate plant and equipment

- a safe place of work, and

- a safe system of working

These duties, originating in the nineteenth century, are now of limited importance in practice because of the development of the statutory duties, discussed below. There are several reasons for this. Although they cannot be delegated to another, the common law duties require the employer, or his agent, to be shown to be at fault. In contrast, many statutory duties give rise to strict liability. In addition, the defence of voluntary assumption of risk cannot apply in a statutory duty case. The statutory duties are more precise, usually being set out in the legislation in considerable detail when compared to the vague generalities of the common law. They offer much clearer guidance concerning the factors affecting, for example,

135 Lister $v$ Hesley Hall [2002] 1 AC 215. 
whether there is a safe place of work, or when liability might arise for manual handling, or using work equipment. As a result, in practice only the common law requirement to provide a safe system of work has much effect, and even then, in many cases, it is often included by lawyers in the pleadings only as a makeweight argument. However, the duty to provide competent staff may still have some value in extending liability beyond that imposed vicariously because it makes the employer liable even for staff acting outside the course of their employment, as where injury is sustained as a result of horseplay or deliberate assault by a fellow worker.

\section{Breach of statutory duty}

109 Health and safety legislation, beginning at the very end of the nineteenth century, was primarily designed to regulate workplace risks by setting up an administrative system to inspect premises and direct measures to prevent injury. It was backed by various enforcement powers, and if necessary, the criminal law. However, the tort system soon adopted and, in many ways, warped this legislation so that nowadays its primary legal function is to enable injured workers to obtain compensation in tort. It does so by creating a presumption that violation of the criminal law in relation to health and safety amounts to a breach of the standard of care required in tort. In fact, the legislation has been more commonly employed in the civil law to create an action for breach of statutory duty than it has been used in the criminal law to punish offenders.

110 As the result of the implementation of various directives of the European Community the UK now has a very comprehensive and detailed set of regulations covering all aspects of work safety. In particular, a group of regulations enacted in 1992 had wide effect, partly because the rules they created are not specific to particular industries or trades as were the regulations they replaced. Instead the rules now apply to offices, shops, factories and other workplaces alike. Although they are now a very important source of civil liability and extensively used by practitioners, the regulations are not discussed in detail in tort textbooks and academic law journals pay them very little attention.

111 Whether a regulation imposes strict liability upon an employer depends upon how it is worded. Some duties are absolute and allow for no excuse, as where escalators are required to function safely. ${ }^{136}$ Other duties are

136 The Workplace (Health, Safety and Welfare) Regulations (1992) (SI No 3004) reg 19. 
subject to qualification, as where compliance is needed only 'so far as is reasonably practicable', a phrase which has given rise to a large body of conflicting decisions. Sometimes strict liability has been imposed and the claim has succeeded even though the dangers could not have been foreseen or even though the cost of taking precautions would have been prohibitive. At other times in interpreting 'reasonably practicable' liability has been denied because fault has been absent. Courts have failed to evolve any consistent approach to the problem of whether or not to impose strict liability. A major reason for this, according to one commentator, is that some judges have been influenced by the fact that there is already compensation without fault available under the industrial injuries scheme. ${ }^{137}$ However, in general we can say that the increasing scope of regulation in recent years has led to a stricter liability in tort for work injuries. In particular, the requirement that all employers must now formally 'undertake a suitable and sufficient assessment of the risks' which affect each employee has proved a valuable aid in establishing liability. ${ }^{138}$

Although liability may be strict, this does not mean that causation cannot be used to defeat a claim. For example, it can be argued that the employer's failure to assess the risk is not a cause of the injury suffered if the accident would have occurred anyway. A notable case in which causation was raised to defeat the claim involved an employer who was found not liable even though he was in breach of regulations by supplying safety boots with a small hole. 139 The boots were intended to protect a milk tanker driver against the risk of falling objects. In fact, during freezing weather the driver had to dig out his vehicle from ice and snow. Water penetrated the boot and he suffered frostbite. It was held that this was not the risk against which the boots were intended to guard, and the kind of injury was not therefore protected. The causation argument, in effect, defeated strict liability.

\section{Effect of the victim's contributory conduct}

Unlike under the industrial scheme, the victim's conduct can form the 113 basis for the partial defence of contributory negligence. This results in a reduction of the damages to be paid. Until legislation was passed in 1945

137 Atiyah's Accidents (fn 15) 98.

138 The Management of Health and Safety at Work at Regulations 1999 (SI No 3242) reg 3.

139 Fytche $v$ Wincanton Logistics Ltd [2004] 4 All ER 221. 
any fault on the part of the claimant would have led to the action being barred, but now the damages can be apportioned according to the parties' share of responsibility for the injury caused so that the claimant will usually obtain most of his damages. ${ }^{140}$ Contributory negligence reduces damages in about a quarter of all tort claims whereas no such reduction can take place under the industrial scheme because it is not based on fault whether it be of the employer, another employee, or the claimant himself. 141

114 In tort there remain several possibilities for avoiding liability entirely. First, as we have seen immediately above, causation arguments can be used to show that the employer's breach of duty was not legally the cause of injury. Secondly, if the claimant's conduct is such as to take him outside the course of his employment his claim is likely to fail because he will not be able to rely upon those duties of care which would be owed to him whilst doing his job. ${ }^{142}$ Finally, in very rare cases the defence of voluntary assumption of risk might apply to defeat the entire claim, although it has been held that this cannot be argued where a breach of statutory duty forms the basis for the action. Until the 1940s voluntary assumption of risk, contributory negligence and common employment comprised the 'unholy trinity' of defences which helped to ensure that very few claims by workers ever reached the tort system.

\section{Scope of protection}

\section{Accidents and disease}

115 Unlike under the state scheme, tort claimants seeking compensation for disease are not confined by a set list prescribing the illnesses or conditions covered and limiting compensation to particular employments. Instead they can sue upon proof that the disease was caused in the individual circumstances of their work. However, tort is similar to the industrial scheme in that both systems favour those injured by accident rather than disease. Those involved in accidents are more ready to attribute responsibility and sue for their injuries partly because the cause of their misfortune is clear. By contrast, victims of disease may not realise that they have been injured by another's wrongdoing, and may find great difficulty in

140 Law Reform (Contributory Negligence) Act 1945.

141 Harris et al (fn 67) 91.

142 Discussed in relation to the industrial scheme at nos 41-44. 
attributing cause perhaps some years after their initial exposure to substances at work. ${ }^{143}$ As a result far fewer claims are made in tort for disease than for accident: in the three years from 2007 to 2010 there were 2.4 million claims made for all types of personal injury but only 49,000 of these related to disease, being about one in fifty of the total. ${ }^{144}$ Within that three year period there were 253,000 work injury claims, but diseases constituted only about one fifth. In fact, therefore, in spite of an openended system in tort, there are disproportionately fewer claims made for disease than under the closed list industrial scheme where new claims for disease now equal those for accident. 145

In spite of these figures we can say that tort has increasingly recognised the $\mathbf{1 1 6}$ hidden effects of work upon health and this has been reflected in litigation statistics. For example, greater knowledge of the risks of repetitive manual movements, or of asbestos, or noise at work has at different times resulted in many new cases being brought. In particular, the claims of miners in respect of, firstly, respiratory disease, and secondly, the use of vibrating tools led to settlement schemes which were called 'the biggest personal injury schemes in British legal history and possibly the world'. ${ }^{146}$ From 1999-2004 about 760,000 of these particular claims were registered. Under the respiratory disease scheme $£ 2,300$ million was paid out, and under the vibration scheme a further $£ 1,700$ million. ${ }^{147}$ Whereas the median award for vibration was $£ 8,300$, for respiratory disease it was only $£ 1,500$. The cost of administration was very high: lawyers' costs under the respiratory scheme averaged $£ 1,920$ out of a total cost of $£ 3,200$ required to administer each claim. ${ }^{148}$ These settlements have all now been concluded and this accounts for the substantial fall in the number of disease claims in the more recent figures of actions brought in tort for personal injury.

\section{Personal injury}

It is usually all too apparent whether or not the claimant has suffered an actionable personal injury. However, a rare case in which the issue was

\footnotetext{
143 Stapleton (fn 66).

144 Compensation Recovery Unit reply to a Freedom of Information Act request, 14 April 2010.

145 No 58 above.

146 Department of Trade and Industry, Coal Health Claims <http://www.dti.gov.uk/ coalhealth/01.htm>.

147 House of Commons Parliamentary Debates, 25 June 2009, Written Answer at column c1110W.

148 National Audit Office, Coal Health Compensation Schemes, HC 608 session 2006-07.
} 
raised was where workers had been exposed to asbestos and had developed pleural plaques which were asymptomatic. ${ }^{149}$ They were denied compensation because the damage they had suffered had not made them physically worse off; the change in condition, of itself, was insufficient to ground the action.

118 Liability for personal injury includes any form of mental injury or distress if accompanied by physical injury. Even mere upset or minor disturbance causing a sleepless night can then be compensated. However, where there is no physical injury and only mental injury is suffered there are special rules which limit recovery. For example, entitlement depends upon proving that a recognised psychiatric illness has been suffered. Only the more severe forms of mental suffering will suffice. ${ }^{150}$ Again, therefore, the tort system is similar to the industrial scheme in strictly limiting these types of claim. However, it is true to say that they have increased in number in recent years, and vulnerable employees for whom no special provision is made are now better able to seek redress from tort if work is a cause of their mental breakdown. ${ }^{151}$

\section{Other than personal injury}

119 Liability can extend to compensation for damage to workers' property. However, it is not compulsory to insure against such loss as it is in the case of personal injury. Property loss, if any, in an employer's liability case is usually very small indeed and it rarely figures in settlements.

120 An employer has no liability to reimburse pure economic losses. Thus the loss of wages resulting from temporary closure of a factory production line as a result of an accident cannot be claimed in tort by those who do not suffer physical injury. An employer owes no duty to protect his employee from economic loss caused by a third party for whom the employer is not responsible. Specifically, for example, he owes no duty of care to advise his employee to obtain personal accident insurance against special risks arising out of his posting overseas. 152

121 The common law also does not provide any compensation for dignitary injuries resulting from discrimination or sexual harassment. However, scope for such claims can be found in general employment, harassment

149 Rothwell v Chemical \& Insulating Co ltd [2008] 1 AC 281.

150 For details see Rogers (fn 24) para 5-61 ff; Deakin/Johnston/Markesinis (fn 24) 139-156.

151 Hatton v Sutherland [2002] 2 All ER 1.

152 Reid v Rush and Tomkins [1990] Industrial Cases Reports 61. 
and anti-discrimination legislation. ${ }^{153}$ For example, a claim can be brought in an employment tribunal if the employer has unfairly dismissed the employee, or his actions can be taken as constructively amounting to such a dismissal. The claim must be started within three months. Compensation is available for financial loss only and not for injury to feelings. The basic award depends upon the employee's age and length of service but this is supplemented by a compensation award which offers recompense for the financial loss. However, it takes no account of injury to feelings. At present the upper limit for this compensation award is $£ 68,400,154$ although it is rare for a tribunal to award such a sum unless the employee is a very high income earner. To avoid these statutory limits in tribunals, an employee can apply to the courts for wrongful dismissal, although this is an unusual and more risky course of action.

Under the Protection from Harassment Act 1997 a claim may be brought in respect of conduct calculated to cause distress and judged to be oppressive and unreasonable. ${ }^{155}$ The conduct targeted at the claimant must occur on at least two occasions. It is viewed objectively, and need not amount to criminality. ${ }^{156}$ The Act is more generous than either tort or the employment legislation because it allows the claim to be brought anytime within six years of the conduct. In addition, compensation is available for mere anxiety and it is not necessary to show that a positive psychiatric injury has been suffered. Anxiety and distress alone would not attract compensation in tort or under the employment legislation. As in tort, proceedings under the Act are taken via the traditional court system rather than through an employment tribunal. There are then no financial limits on the damages that can be obtained so that $£ 800,000$ was awarded in one case. 157

A more general basis for claiming on various grounds of discrimination now lies under the Equality Act 2010. This offers protection against discrimination on the basis of sex, age, religion, disability and sexual orientation. Action against an employer can be taken for failure to take reasonable steps to prevent discrimination even if it is from a third party, such as another employee or even a customer. Although damages are unlimited, in practice compensation awarded for injury to feelings alone

\footnotetext{
153 S Deakin/G Morris, Labour Law (5th edn 2009); I Smith/G Thomas, Employment Law (9th edn 2007); N Bamford/M Malik/C O’Cinneide, Discrimination Law (2008).

154 Employment Rights (Increase of Limits) Order 2010 (SI No 2926) effective February 2011.

155 Thomas v News Group Newspapers [2001] All ER 246.

156 Veakins $v$ Kier Islington Ltd [2010] Industrial Relations Law Reports (IRLR) 132.

157 Green v Deutsche Bank [2006] IRLR 764.
} 
do not exceed $£ 30,000,158$ and usually are very much lower. Further sums are payable for loss of earnings or as exemplary damages.

\section{Heads and levels of damages}

124 Damages in employers' liability cases are assessed in the same way as for any other type of personal injury; there are no special rules. Compensation can be obtained for both the pecuniary and non-pecuniary losses resulting from injury or death. The main heads of financial damage are lost earnings and pension losses, with the costs of care and rehabilitation accounting for the greater part of the award in the most serious injury cases.

125 Overall non-pecuniary loss accounts for a disproportionate amount of damages. It was two thirds of the total awarded thirty years ago, ${ }^{159}$ and it has remained at about that level. This extraordinary importance given to pain and suffering reflects the fact that most awards are for relatively small sums averaging less than $£ 5,000.160$ In these cases claimants suffer very little, if any, financial loss. They make a full recovery from their bodily injury and are left with no continuing ill effects. In most cases the accident does not result in any claim for social security benefit. However, a few claims are much more serious. In 2002 insurers estimated that $1 \%$ of all cases in the tort system, whether or not involving work injury, resulted in a payment of $£ 100,000$ or more. These few cases were responsible for $32 \%$ of the total damages paid out by the system. ${ }^{161}$

126 Damages in tort traditionally have been paid only in the form of a lump sum. This is in stark contrast to disablement benefit under the industrial scheme which can only be paid as a pension. Although a lump sum is obviously the most efficient way of disposing of the mass of small claims, it has attracted much criticism when proving insufficient in cases of long term injury. There are several reasons for the inadequate provision. For example, the once and for all payment cannot be reviewed to cater for a later unforeseen deterioration in the claimant's condition, although there

\footnotetext{
158 Da' Bell v National Society for Prevention of Cruelty to Children [2010] IRLR 318.

159 The Pearson Report (fn 12) vol 2 table 107.

160 The median figure was $£ 2,500$ in the survey of 81,000 cases receiving legal aid and closed in 1996-97 in P Pleasence, Personal Injury Litigation in Practice (1998) 40 fig 3.17. P Fenn and N Rickman (Costs of Low Value Liability Claims 1997-2002) report average damages of only $£ 3,000$ for employers liability accident claims, although this study of almost 100,000 cases related only to claims for less than $£ 15,000$. Department for Constitutional Affairs, <http://www.dca.gov.uk/majrep/claims/elclaims.htm>.

161 Lord Chancellor's Department, Regulatory Impact Assessment on the Courts Bill (November, 2002) table 1.
} 
is a very limited 'provisional damages' procedure which offers additional payment if a risk identified in a court order actually materialises. Again, the traditional lump sum payment cannot be supplemented if the claimant outlives the life expectancy projected when the award was made, or if inflation or market fluctuations erode the money. Because of these criticisms, a new way of paying damages has been developed: in some tort cases which involve future loss it is now possible to obtain periodical payments instead of the lump sum.

Periodical payments in the form of 'structured settlements' have been available since 1989 and have been increasingly used in cases of very serious injury. ${ }^{162}$ Following legislative intervention, a periodical payment order must now be considered by a judge in every case involving personal injury which comes to court if it involves future pecuniary loss. ${ }^{163}$ Periodical payments can then be ordered even if this is opposed by either or both of the parties. 164 There is no longer any need to work out the lump sum equivalent of the periodical award. Instead the court assesses the periodical payments needed by the claimant irrespective of their capital cost. This is a major change in the way in which damages are assessed and paid. Another feature is that, as a guard against inflation, it has been agreed that the pension is to be increased in line with a much more favourable index than that used in calculating the present day value of a lump sum. ${ }^{165}$ As a result of this particular advantage there has been a significant increase in the number of cases involving periodical payments where serious injury is involved; it has become the way in which damages must be paid if certain claimants are to receive their full losses. In particular, to secure the long term cost of nursing care a periodical award must be sought. Again, however, for periodical payments no special provision is made for work injury cases.

\section{E. Administration of claims}

Tort claims for work injury are dealt with by the usual courts administer- $\mathbf{1 2 8}$ ing civil justice. No specialised tribunals or procedures are involved.

162 R Lewis, Structured Settlements: the Law and Practice (1993); N Bevan/T Huckle/S Ellis, Future Loss in Practice: Periodical Payments and Lump Sums (2007).

163 Courts Act 2003 s 100.

$164 \mathrm{R}$ Lewis, The Politics and Economics of Tort Law: Judicially Imposed Periodical Payments of Damages (2006) 69 Modern Law Review (MLR) 418.

165 Thompstone $v$ Tameside and Glossop Acute Services NHS Trust [2008] 2 All ER 537; R Lewis, The Indexation of Periodical Payments of Damages in Tort: The Future Assured? (2010) 30 Legal Studies 391. 


\section{Number and cost of claims}

129 In $2010-11$ work related injuries comprised about $8 \%$ of all personal injury claims, being 81,000 out of a total of $987,000 .{ }^{166}$ This is almost twice the number of claims that are made for industrial injuries benefit, and in part reflects the high threshold of injury now required to establish a benefit claim. However, there are four times as many industrial disablement pensions actually in payment compared to the number of tort claims for work injury. These 324,000 pensions reflect the accumulation of entitlement to benefit in previous years. Therefore, although every year there are more people who receive industrial benefit than a tort award, this is only because the method of compensation of the benefit involves continuing payments in contrast to the single lump sum that is usually awarded in tort.

130 Although work-related tort claims may appear numerous in fact they have declined in recent years. In 1978 they were the most common type of action, accounting for $46 \%$ of all personal injury claims. ${ }^{167}$ Now they account for only $8 \%$ of all claims. The major reason for this is the continued rise of motor claims which now constitute four out of five cases. ${ }^{168}$ It has always been the case that a smaller proportion of those injured at work sue in tort compared to those injured by motor vehicles. In 1978 it was found that whereas one in four injured following a road accident made a claim, only one in ten did so following a work accident, and only one in 67 did so if they were injured elsewhere. ${ }^{169}$ In spite of stricter liability for work injuries it remains the case that there are many employees who do not claim.

131 The decline of work claims in the statistics reflects a decline in employment in traditional industries where often danger was ever-present; few employees are now involved in making iron and steel or in mining coal.

166 Work injury settlements, rather than new claims made, comprised about $11 \%$ of the total in that year and numbered 98,000. Department for Work and Pensions, Compensation Recovery Unit - Performance Statistics <http://www.dwp.gov.uk/other-specialists/compensation-recovery-unit/performance-and-statistics/performance-statistics $>$.

167 alone.

The Pearson Report (fn 12) vol 1 table 5. The table also reveals that overall only $6.5 \%$ of all accident victims are compensated by the tort system. However, if only serious injuries are considered tort becomes more important. Where an accident causes incapacity for work for six months or more, almost a third of claimants receive tort damages. 
Workplace injuries have fallen substantially in the last five years: in 201011 there were 115,000 injuries reported to the Health and Safety Executive, 39,000 less than in 2005.170 The decline in tort actions in recent years also reflects the fact that a spike of claims under the special schemes of compensation for disease has now worked its way through the system and no longer affects the statistics. These schemes alone accounted for 760,000 tort claims in the five years from 1999 as discussed above. ${ }^{171}$

On average in the five years to 2008 insurers paid out about $£ 1.5$ billion a year in employers' liability settlements including legal costs. This contrasts with the cost of benefits alone under the industrial injuries scheme of about $£ 800$ million a year. There were about 186,000 settlements of work injury cases a year in tort during that five year period. ${ }^{172}$ The average amount per settlement was therefore about $£ 8,000$ Given that the claimants' legal costs constitute over $30 \%$ of the total, claimants received on average about $£ 5,000$ per claim, ${ }^{173}$ the equivalent of a little over three months average weekly earnings. Settlements have since declined to 98,000 in 2010-11, and now that the special schemes of compensation have ended, new claims themselves have fallen to only 81,000. It can therefore be anticipated that the total cost of the fewer tort claims now being made will fall to about the same level as the present expenditure upon the no-fault scheme. One factor which may affect this is that, although fewer tort claims are being made, the cost of each of them continues to rise: in the ten years from 1996 the cost of motor claims rose by over twice the rate of inflation. ${ }^{174}$

\section{Insurers and the administration of the tort system}

Almost all defendants in tort are insured against their liability, including employers who are required by legislation to be so. This has a considerable effect upon the administration of the tort system. The practices of insurance companies are essential to the understanding of how the tort system

170 Health and Safety Executive, Statistics 2010/11. <http://www.hse.gov.uk/statistics/overall/hssh1011.pdf $>$.

171 No 116.

172 Association of British Insurers statistics for 2008 cited by the Department for Work and Pensions, Accessing Compensation (2010) para $31<\mathrm{http}: /$ www.dwp.gov.uk/docs/ elci-compensation-consultation.pdf $>$.

173 Ibid para 42 at note 24 .

174 International Underwriting Association of London (fn 23). The reasons are examined in R Lewis/A Morris/K Oliphant, Tort Personal Injury Claims Statistics: Is there a Compensation Culture in the UK? (2006) 14 Torts Law Journal 158. 
actually works. In $98 \%$ of tort cases the claim is settled out of court, 175 and the factors affecting the bargains that are struck may be very different to the strict rules of law that would be applied by a judge. Rough and ready rules are applied to dispose of claims as efficiently as possible, especially given the low sum of damages usually being sought.

134 Insurers process these routine payments and they decide which elements of damage they will accept or contest. It is unusual for them to contest liability, one study revealing that insurers' files 'contained remarkably little discussion of liability', finding it initially denied in only $20 \%$ of cases. ${ }^{176}$ As a result, eventually insurers make at least some payment in the great majority of personal injury claims, often because the costs are such that they are not worth contesting too vigorously. It has been suggested that about $95 \%$ of work injury cases supported by trade union solicitors result in some payment to the claimant. ${ }^{177}$ Tort thus provides a structure for processing mass payments of small amounts of compensation; only very rarely does it stage a gladiatorial contest to determine whether a particular defendant was in the wrong. Contrary to the impression gained from tort textbooks, duty of care, causation of damage, and even breach of duty are generally not in dispute in employers' liability cases processed by the system.

135 Classic empirical studies reveal that, in practice, the rules of law are much less important than the tort textbooks might lead one to suppose: it is insurance bureaucracy that dictates the course of the litigation, and determines whether, when, and for how much, claims are settled.178 The important centres of personal injury practice are insurers' buildings, rather than courts of law, or even solicitors' offices. Insurers decide, in particular, whether a case merits the very exceptional treatment of being taken to a court hearing. In effect, insurers allow trial judges to determine only one per cent of all the claims made. Only a few of these are appealed with the result that the senior judiciary are left to adjudicate upon a small fraction of what are, by then, very untypical cases. Insurers are of fundamental importance to the administration of tort claims for personal injury. 179

175 The Pearson Report (fn 12) vol 2 table 12. Similarly Pleasence (fn 160) at 12 revealing that only 5 out of the 762 cases studied went to trial.

$176 \mathrm{~T}$ Goriely/R Moorhead/P Abrams, More Civil Justice? The Impact of the Woolf Reforms on Pre-Action Behaviour (2002) 103.

177 Citizens Advice Bureau, No Win, No Fee, No Chance (2004) para 4.31.

178 H Genn, Hard Bargaining (1987), Harris et al (fn 67) and, in the USA, HL Ross, Settled Out of Court (1980).

179 R Lewis, How Important are Insurers in Compensating Claims for Personal Injury in the UK? (2006) 31 Geneva Papers on Risk and Insurance 323. 
In contrast, private insurers now have no part to play in the state-run industrial injuries scheme. All claims are adjudicated, and there is no question of a claimant accepting a deal outside the tribunal for a lesser sum than that to which he is entitled. The discretion of those administering the system plays little part and, unlike in tort, almost all disputes focus upon basic entitlement to benefit rather than the amount due.

\section{The speed of settlement}

Whereas benefit claims are resolved within three to eight months, tort claims take much longer. Even though small sums are usually involved, the majority take between one and two years to process and settle. ${ }^{180}$ If a case goes to court the time taken is much longer, averaging between three and five years. ${ }^{181}$ The more serious the injury, the longer the time it takes. ${ }^{182}$ It has been observed that 'if it were not for the social security system, which provides many claimants with benefits during the settlement process, the tort system would probably have collapsed long ago'.183

\section{The administrative cost of tort}

The cost of operating the tort system amounts to $85 \%$ of the value of tort payments distributed to claimants. ${ }^{184}$ That is, for every pound received by

180 The Department of Social Security reported an average settlement period of 2.3 years for those tort cases where benefits were recouped from 1990-94, although in $28 \%$ of cases the recoupment period lasted for between three and five years. See the DSS Memorandum of Evidence to the Social Security Select Committee (1995) HC 196 appendix B. Similarly, the median duration of a legally aided tort case where proceedings were issued was found to be 2.4 years by Pleasence (fn 160) 65 fig 4.21. The Pearson Report (fn 12) vol 2 table 17 found that $49 \%$ of claims settled within a year and $80 \%$ within two years of injury.

181 The Pearson Report (fn 12) vol 2 table 129, and similarly the Lord Chancellor, Report of the Review Body on Civil Justice (1988, cmd 394).

182 In a study of 153 cases where compensation of $£ 150,000$ or more was obtained in 1987 and 1988 the average time for settlement was 5 years 4 months. P Cornes, Coping with Catastrophic Injury (1993) 18.

183 Atiyah's Accidents (fn 15) 283.

184 The Pearson Report (fn 12) vol 1 para 256. The Lord Chancellor's Report of the Review Body on Civil Justice in 1986 estimated that the cost of the tort system consumed 50 to $70 \%$ of the total compensation awarded in personal injury cases. Lord Justice Jackson found similarly very high costs in his Review of Civil Litigation Costs: Final Report (January 2010). Data collected for one survey showed that for 280 cases which had come before the District Court the claimant costs alone amounted to $£ 1-80 \mathrm{p}$ for every $£ 1$ of damages paid. On average, costs exceeded damages for cases settled up to $£ 15,000$ in the 'fast track' procedure. 
the claimant, the greater part of another pound is consumed in costs. Put another way, for every pound spent upon the system in total, 55 pence goes to the claimant and 45 pence in costs. These costs include not only the legal costs on both sides which insurers have to meet, but also insurers' costs in administering the system. The claimant's legal costs alone are about $30 \%$ of the damages awarded. ${ }^{185}$

139 The very high cost ratio contrasts with the very much lower figures given for administering industrial injuries social security payments. ${ }^{186}$ The industrial scheme is much more cost effective because it is based on nofault, involves few lawyers, and uses the tribunal system rather than the traditional court structure. However, both systems focus upon minor injury claims where costs are likely to be out of proportion to the compensation paid.

\section{F. Rights of recourse}

\section{Rights of recourse against other employees}

140 In theory in a case of vicarious liability an employer can reclaim any damages paid from the negligent employee who caused the injury. ${ }^{187}$ However, in practice this does not happen. This is because the legal decision which confirmed the subrogation right of the employer's insurer to stand in the shoes of the employer was very soon overturned by a private agreement which prevented all insurers from reclaiming the damages from the negligent employee. When the legal decision allowing subrogation was made in 1957 it was immediately condemned not only by trade unionists but also by many employers. It was considered to be extremely bad for industrial relations. As a result, employers' representatives met with insurers and privately agreed that an indemnity from the negligent employee would never be sought unless there had been collusion or wilful misconduct by the employee. ${ }^{188}$ The Association of British Insurers continues to maintain a committee to supervise this agreement.

185 International Underwriting Association of London (fn 23) para 7.21.

186 No 85 above.

187 Lister $v$ Romford Ice and Cold Storage Co [1957] AC 555.

188 The agreement was examined in detail in Morris $v$ Ford Motor Co Ltd [1973] Queen's Bench (QB) 792; $R$ Lewis, Insurers' Agreements not to Enforce Strict Legal Rights: Bargaining with Government and in the Shadow of the Law (1985) 48 MLR 275 at 282. 


\section{Rights of recourse against third parties}

An employer could seek to reclaim damages from any negligent third party under the Civil Liability (Contribution) Act 1978. In effect this could also be done by the employer joining the third party to the action brought by the claimant, and seeking to apportion the damages among the joint tortfeasors. Negligent parties could include, for example, the suppliers of the defective equipment which caused the injury or the contractor also responsible for safety on the site. Where injury is caused by a motorist in the course of employment certain insurers have privately agreed that only the employer's liability insurer will pay the damages and the motor insurer will not be liable. ${ }^{189}$

\section{G. Interaction with social welfare systems and private insurance}

\section{Recourse of social security agency against the employer}

Historically, the relationship between damages for personal injury in tort and social security has been fraught with difficulty. However, a much clearer picture has emerged following the comprehensive benefit recovery system set up twenty years ago. This enables the state to reclaim the precise social security benefits paid for an injury in each case where any payment of damages in tort for personal injury is later made. Subject to certain limits, all benefits paid as a result of the tort can be recovered from whoever pays the damages. This scheme was outlined in an earlier book in this series, ${ }^{190}$ and it has been considered by the author in detail elsewhere. 191

In the great majority of work injury cases the compensator required to repay the benefits is the employer's liability insurer. As exceptions to this, a few large employers and government organisations are allowed to selfinsure and pay damages directly themselves. However, if no tort claim is brought, benefits cannot be recovered even though it may appear that an employer was responsible for the injury. The state has no independent right of recourse against a tortfeasor; its reimbursement is parasitic upon the claim in tort brought by the injured employee. There are no bulk

189 E Whitmore, Employers' Liability Insurance (1962) 158 and appendix vii.

190 Magnus (fn 18) 56-85.

191 R Lewis, Deducting Benefits from Damages for Personal Injury (1999). 
recovery agreements as there are in other EU countries which enable levies to be raised from insurers in a broad brush fashion.

144 The state had no such right of recourse until 1990. Legislation then established the Compensation Recovery Unit as a state agency to claw back the welfare benefits paid to accident victims up to the date of the settlement of their damages claim. ${ }^{192}$ In practice, this agency rarely needs to mount a separate recourse action to recover the benefit paid. This is because, in each case where damages for personal injury are to be paid, the compensator is first required to investigate the benefits which have been paid to the claimant as a result of the injury. A computerised system produces very accurate certificates of the amount of benefit in question. Then, on paying the damages, the compensator has a duty to repay the amount in the certificate to the Recovery Unit. This reimbursement has become routine, and is part of the administrative process involved in disposing of every successful tort claim. Industrial injury disablement benefit is specified as one of the benefits to be recovered and represents about $15 \%$ of the total amount recovered by the state. ${ }^{193}$ In 2009-2010 that total was $£ 139$ million of which $£ 75$ million related to work injuries. ${ }^{194}$ Although work accidents account for less than $10 \%$ of claims in tort they are therefore responsible for over half of the benefits recovered.

145 The period during which benefit can be recovered begins, in the case of an accident, on the day after it happened. In the case of a disease it begins on the day on which the first claim for benefit in respect of the disease was made. The period of recovery ends either five years after the recovery period began, or on the date when final compensation is paid, whichever is sooner. In practice this means that in the vast majority of cases the recovery period ends on the date of settlement of the case because most claims are concluded well within the five year cut-off period. The state cannot recover benefits which may be paid to the claimant in the future, that is, after the settlement agreement or court order. This limit means that the industrial accident victim who continues to receive disablement benefit for the rest of his life will receive compensation which may overlap with any provision also made by the tort system for his future loss.

192 Social Security Act 1989. Major revisions were made eight years later, the current legislation being the Social Security (Recovery of Benefits) Act 1997.

193 Based on a private reply to the author from the Department for Work and Pensions in 2006 and relating to $2004-05$. Over $£ 24$ million in disablement benefit was recovered that year.

194 Department for Work and Pensions (fn 166) <http://www.dwp.gov.uk/other-specialists/ compensation-recovery-unit/performance-and-statistics/performance-statistics>. 


\section{Reducing damages to take account of the benefits paid}

Although the compensator has a duty to repay the benefits received in full, 146 in most cases the cost of doing so is reduced because the compensator is allowed to set off the benefits against part of the damages due to the injured person. The amount of damages paid is therefore reduced. As a result, in theory, the claimant then obtains no more than he has lost, the defendant pays in full, and the public purse avoids bearing the cost of financially supporting those injured by another's wrongdoing. The scheme is attractive because it appears to avoid not only subsidising the defendant but also over-compensating the accident victim, at least during the period before his damages claim is settled.

Although the compensator can set off the benefit he must repay to the state against certain parts of the damages for which he is liable, he is limited in the extent that he can reduce the damages that must be paid to the claimant. In particular damages for non-pecuniary loss are 'ringfenced' so that no industrial injuries or any other benefit can be deducted from them. Although industrial injuries benefit itself in effect is a form of non-pecuniary loss, the recovery scheme allows only for it to be deducted from damages paid for income loss.

The compensator's ability to reduce damages places considerable pressure upon claimants to settle their cases as soon as possible. The incentive for claimants is 'settle today and keep tomorrow's benefits; settle tomorrow and you will lose them'. In some circumstances the time factor can also be used as a bargaining tactic to persuade the compensator to accept the terms offered. The social security system thus has an effect not only upon the value of a tort claim but also upon the way in which it is administered and the speed with which it is settled.

\section{Recovering the cost of National Health Service treatment}

The benefit recovery scheme has been extended to enable the cost of hospital treatment provided under the National Health Service to be recovered. ${ }^{195}$ The scheme is parasitic upon the benefit recovery scheme, and requires the repayment of costs to be made at the same time that tort damages are paid to the claimant. Of course, this includes the cost of NHS

195 Originally under the Road Traffic (NHS Charges) Act 1999 and now the Health and Social Care Act 2003. R Lewis, Recovery of NHS Accident Costs: Tort as a Vehicle for Raising Public Funds (1999) 62 MLR 903. 
treatment for the victim of industrial injury. The payment due is based on a fixed charge related to the number of days of hospital treatment and the use of ambulances. The maximum recoverable in any one case is about $£ 44,000$. Compensators were required to pay a total of $£ 195$ million in 2010-2011'196 this being $40 \%$ more than the amount of social security benefit recovered that year. ${ }^{197}$ Health benefit recovery is therefore now more important than that for social security.

\section{H. Insurance}

\section{The scope of compulsory insurance}

150 It was not until 1972 that it became compulsory for an employer to insure against liability to employees injured in the course of their employment. ${ }^{198}$ Separate policies are issued instead of cover being combined within, for example, policies issued for public liability in general or for liability for motor vehicles. All employers are required to insure except for nationalised industries, health service bodies, local authorities and certain public bodies who are otherwise able to guarantee their liabilities. However, small family businesses are also exempt from obtaining employers' liability insurance provided that the employees are all close family members. This has been the subject of criticism because this exemption is not granted in motor insurance when close family members are being carried in the vehicle. It is not obvious why a farmer should be compelled to insure his sons when being carried in his car, but not when driving a tractor in the fields or helping him with what may be other dangerous tasks involved in his work. ${ }^{199}$ Employers must be insured only up to $\mathrm{f5}$ million, a sum which has not kept pace with inflation and is thought insufficient in the event of multiple claims in respect of a major accident. By contrast motorists must carry unlimited liability for causing death or

196 Department of Health, NHS Injury Costs Recovery Scheme - Amounts Collected <http:// www.dh.gov.uk/prod_consum_dh/groups/dh_digitalassets/documents/digitalasset/ dh_125921.pdf $>$.

197 Department for Work and Pensions (fn 166) <http://www.dwp.gov.uk/other-specialists/ compensation-recovery-unit/performance-and-statistics/performance-statistics/>.

198 Employers Liability (Compulsory Insurance) Act 1969 and the relevant regulations (SI 1998 No 2573); C Parsons, Employers Liability Insurance - How Secure is the System? (1999) 28 Industrial Law Journal (ILJ) 109.

199 RA Hasson, The Employers' Liability (Compulsory Insurance) Act - A Broken Reed (1974) ILJ 79. 
personal injury. The cost of employers' insurance in total is only about $0.25 \%$ of the national payroll. ${ }^{200}$

Failure to comply with the statutory obligation to insure is subject to sanctions in the criminal law. Employers can be fined up to $£ 2,500$ a day, but in practice the fines are low and enforcement is limited. The extent to which there is compliance with the duty to insure varies. One review suggested that only about 1 in 200 employers do not have the requisite cover, ${ }^{201}$ although an earlier survey found a much higher figure for noncompliance. ${ }^{202}$ If an employer fails to insure, there are no reserve funds available to meet the claim as there would be if injury were caused by an uninsured motorist. If the employer has insufficient funds of his own, the injured employee's claim may then be worthless. Overall the insurance system does not protect workers nearly as well as it does motorists.

\section{Policy limits and insurance triggers}

Although employers must be insured up to a minimum of $£ 5$ million for each occurrence, in practice, insurers issue policies with limits of twice that sum. However, whether the loss in question is covered depends upon whether there are further restrictions in the policy because of clauses dealing either with the aggregate limit to liability or with how a series of claims are to be dealt with. ${ }^{203}$ Another problem is with 'long-tail' damage where liability issues arise many years after the policy was issued and the claimant was first exposed to the risk. What triggers liability under the policy and from what date? The answer is usually easy to provide in cases involving accidents because the exact point in time when the sudden event occurs which causes injury is generally easy to identify. However, where the loss occurs gradually, especially if the damage remains undiscoverable for many years, it can be much more difficult to decide whether there is insurance coverage and, if so, which insurer is liable. There have been

200 Department for Work and Pensions, Review of Employers' Liability Compulsory Insurance: First Stage Report (2003) <http://www.detini.gov.uk/dw2583_employers_review.pdf> at 20.

201 Department for Work and Pensions, Review of Employers' Liability Compulsory Insurance: Second Stage Report (2004).

202 The Small Business Service telephone survey of over 2,000 businesses in 2002 suggested that the figure was 1 in 14.

203 Explained more fully in R Lewis, Aggregation and Divisibility of Damage in England and Wales: Insurance, in: K Oliphant (ed), Aggregation and Divisibility of Damage (2009) 125. 
particular problems with claims for cancer or asbestos-related disease. ${ }^{204}$ Broadly there are three possible triggers for the insurance policy: first, when the claimant was initially exposed; second, when physical change first occurs, even if it cannot be discovered; and finally, when the injury becomes manifest. In the USA any of these three triggers has been considered sufficient to gain access to the insurance fund. This helps to ensure that there are no insurance gaps and claimants are more likely to receive compensation. However, in the UK this approach has been rejected as unnecessarily wide. ${ }^{205}$ The most recent case makes the insurer liable when injury was sustained rather than when the claimant was exposed,206 but much depends on the particular facts and the precise wording of the policy. As a result, in individual cases the extent of insurer liability remains certain.

\section{Apportionment}

153 No matter what the trigger, there could be several insurers involved during the relevant period of exposure or development of the disease. There is then the problem of apportioning liability among them. There are various possibilities. For example, the insurers could each be held jointly and severally liable up to their policy limits. Alternatively, they could be held responsible only for a share of the damage based on the different lengths of time they were exposed to risk, or in proportion to the different financial limits in the respective policies.

154 In the key case it was held that the insurers were not liable in full for the damage caused but only to the extent of the probability that the employer they insured had caused the asbestos-related injury. ${ }^{207}$ This could have led to substantial under-compensation of those who had worked for several employers and who, for a variety of reasons, could not sue or enforce a judgment against one or more of them. As a result, the decision led to considerable protest from claimants, their trade unions and their lawyers. The Government immediately took action. For asbestos cases alone involving the disease mesothelioma, the court decision was effectively reversed

204 For discussion in relation to asbestos see C Lahnstein, D Maranger and N Roenneberg's article in: Munich Re Group (ed), 7th International Liability Forum (2003).

205 Bolton v MBC Mutual Insurance Ltd [2006] 1 Weekly Law Reports (WLR) 1492.

206 Durham v BAI (Run Off) Ltd [2010] All ER (D) 88. Appeal to the Supreme Court is awaited.

207 Barker $v$ Corus [2006] AC 572. This applies only where there are alternative and not concurrent causes which cause injury which is indivisible. 
by legislation ${ }^{208}$ which makes defendants liable jointly and severally for the whole of the damage. Asbestos claimants thus gain full compensation even if only one of the former employers has insurance coverage. However, apart from these asbestos cases, the proportionate damages approach adopted in the key case remains good law.

\section{Evaluation and Conclusions}

\section{A. Compensation}

\section{Scope of each scheme}

Both the industrial injuries scheme and employers' liability in tort operate alongside one another in the UK to provide injured workers with about $£ 2$ billion a year. About 120,000 new claims are now made each year under one or other of these schemes, with there being twice as many made in tort compared to the industrial scheme. These figures represent about one claim made for every 240 people in employment, although that figure does not allow for the fact that many of those injured are able to claim both tort damages and industrial benefit.

There are various exclusions from the schemes. For example, both compensate only if workers are injured 'in the course of employment' and their wrongdoing may affect entitlement. Both schemes have had only a limited role to play in compensating victims of disease and ill-health even though these are increasingly being related to work. ${ }^{209}$ In addition, it remains the case that for a variety of reasons many of those injured do not make a claim at all under either scheme. Nevertheless, at least in theory, the two schemes do cover many of the injuries suffered at work even if, in practice, the compensation they provide is less important than the social security system overall in meeting the needs of those who are disabled.

\section{Amount and purpose of compensation}

A key distinction between the two schemes concerns the level of compensation. It is possible for a tort claimant to receive damages of millions of pounds whereas the recipient of industrial disablement benefit can get

208 Compensation Act 2006 s 3.

209 Nos 58 and 116 above. 
only a small fixed pension. Even if we take account of the capitalised value of this inflation proofed pension, it will not compare with the highest awards in tort. However, in practice both schemes are flooded with small claims so that the average award in tort may not be so different from the long-term value of disablement benefit. 210

158 The basis for assessing compensation under the two schemes appears very different. Whereas an objective approach divorced from the claimant's particular circumstances is taken under the industrial injuries scheme, the tort system supposedly tailors its award to the precise losses suffered by the individual. Disablement benefit is fixed by using simple tables related to the degree of disability so that all in the same bracket get the same award irrespective of their real losses. The compensation must be in proportion to the maximum set. By contrast in tort, although there are conventional maxima, there are no such fixed legislative limits. Instead the aim is to return the claimant to the financial future enjoyed before the injury. This ambitious objective makes little difference in minor injury cases but, where there is serious injury, it results in complex computations. Although the approach adds to the expense of dealing with claims, it offers claimants full compensation for their injury, something which often cannot be obtained under the industrial scheme.

159 Full compensation in tort means that damages compensate for both pecuniary and non-pecuniary losses. In contrast, the industrial scheme pays nothing at all for financial losses so that there is no reimbursement for lost earnings or the costs of care. The industrial scheme is therefore very limited in the indemnity it offers. It also privileges what has been classified as a secondary, less important, form of compensation over the primary need for replacement of direct financial loss. ${ }^{211}$ In practice, however, this distinction between tort and the industrial scheme is not quite so clear cut because both systems deal mostly with small claims which cause little if any financial loss. This results in the damages actually awarded in tort being predominantly composed of non-pecuniary loss thus exposing it to the same criticism that can then be levelled at the industrial injuries scheme: both focus upon losses of secondary importance.

160 A final distinction between the two schemes concerns how the compensation is paid. Many problems are caused by awarding damages in tort as a lump sum on a once-and-for-all basis. ${ }^{212}$ To an extent these may be

\footnotetext{
210 Nos 76 and 125 above.

211 Atiyah's Accidents (fn 15) ch 6.

212 No 126 above.
} 
avoided by periodical payments. Disablement benefit can only be paid in this form. The pension can be regularly increased to match inflation and will not run out only because the claimant lives longer than expected. However, in recent years in some serious injury cases tort damages have also been awarded in the form of a pension and the distinction now has a little less force.

\section{Fault and no-fault}

At first sight it may appear that tort is very different from the industrial 161 scheme because it requires proof of fault whereas wrongdoing seems to have little part to play in a claim for benefit. In particular, the defence of contributory negligence reduces damages in about a quarter of all tort claims whereas no such reduction can take place under the industrial scheme. The fault principle has both its critics and supporters. Critics, for example, argue that it is an uncertain standard, difficult and expensive to apply. It often does not correspond to popular notions of moral responsibility for causing injury. ${ }^{213}$ Supporters of the benefit system therefore celebrate the absence of fault from the state scheme.

However, again this difference between the two schemes is not as great as it may seem: fault may not be the great divide. This is because, firstly, under the industrial scheme fault can be relevant in determining not only the course of employment but also causation issues. Secondly, in tort fault is often not required for employers to be liable because strict liability is imposed. We also know that, in practice, because of the uncertainty and the cost involved, fault is contested by insurers in only a minority of claims and only very rarely in cases of low value. In reality, both schemes are predominantly no-fault regimes for less serious injuries. As a result the difference between the schemes may not be as significant as it first appears.

\section{B. Prevention}

Neither the tort nor the industrial injuries system has much effect upon reducing the number of injuries at work. ${ }^{214}$ Both are poor in deterring unsafe practices. The industrial scheme is especially weak because it is now paid for by the state from general taxation and no separate funding

213 Atiyah's Accidents (fn 15) ch 7.

214 Safety and Health at Work, Report of the Committee 1970-72 (1972, Cmnd 5034) (Chairman Lord Robens). 
system exists. Even in the past, when contributions were raised from employers, no account was taken of the relative risk posed by different industries because differential rating was thought ineffective in reducing claims. ${ }^{215}$ In contrast, the tort system does not involve state funds. It is paid for by employers alone with the cost in practice falling upon private insurers. On the surface there appears to be a risk relationship because insurers require differential premiums from employers. However, this has been thought a very ineffective means of influencing risky behaviour. Only half of all employers engage a sufficiently large number of workers in order to be rated according to their own accident experience. Instead most employers are classified alongside others of a similar kind and the premiums that they pay are then unaffected by accidents that occur at their particular workplace. More direct action by insurers in giving advice concerning risks can have some effect, but the scope for this is limited. ${ }^{216}$ More important incentives to avoid injury are the costs associated with the general disruption to the work process when an accident occurs rather than the price that has to be paid as a result of any action in tort. Both tort and the industrial scheme have been of some help in identifying the cause of injury but overall they have had little effect upon reducing the incidence of injury.

\section{Overall costs}

164 There are considerable differences between the schemes with regard to their administration and efficiency in delivering compensation. The tort system is much less accessible and much more expensive to run than the state scheme. It is administered largely by private insurers using the traditional civil justice court system. Lawyers are closely involved, although most cases are settled well before formal legal proceedings are begun with only $1 \%$ of cases being determined by a judge in court. In contrast, the industrial injuries scheme is run by the state via a more informal tribunal system. All cases are determined by an adjudicating authority and never settled as a result of a bargain. Lawyers are much less likely to play a part. As a result there is a major difference in the cost of delivering compensation: whereas the tort system costs $85 \%$ of the compensation it pays out, the industrial scheme costs only $2 \% .217$ Claimant

\footnotetext{
215 No 80 above.

216 Dewees/Duff/Trebilcock (fn 23); Armstrong/Tess (fn 109) and Atiyah's Accidents (fn 15) ch 17. For a more equivocal view see Rogers (fn 24) paras 1-29 ff.

217 Nos 85 and 138-139 above.
} 
legal costs alone in tort are over $30 \%$ of damages paid and these must be borne by insurers. The difference in the systems also means that it takes more time for tort damages to be paid even in minor injury cases. When serious injury is involved this difference can be measured in years rather than months. Justice delayed then can often mean justice denied.

Of course, these criticisms of tort can be countered by pointing to the reasons for the delays and costs involved: the subjective assessment of damages in tort may be complex but it can offer much more compensation for seriously injured claimants than the simple mechanical objective formula used to arrive at the industrial pension; tort lump sums necessitate delay in order to assess the full effects of claimants' injuries; and lawyers supposedly offer greater sophistication, accuracy and justice when determining entitlement. Nevertheless, the difference in administration and efficiency between the two systems here is very considerable.

\section{Interaction between workers' compensation and private law}

Both systems add to the complexity of the compensation structure overall and necessitate special rules to deal with overlapping compensation from collateral benefits. The criticism is that a wasteful system involving duplicate payments presently exists. In the past twenty years a new state agency has been established to recover the social security and health costs of injuries which result in an award of damages in tort. This requires a detailed analysis of each claim paid and it results in additional cost. However, the state recovers over $£ 335$ million a year from the scheme and now has an interest in each tort claim brought. From the claimant's viewpoint, where benefits are initially received they can be seen as merely short-term loans from the state to tide them over until they obtain their tort damages. However, the recovery scheme does help to minimise duplication of payment from the different sources and the possibility of over-compensation. ${ }^{218}$

\section{E. Plans for reform}

There are no major plans to reform the substantive law relating to either the industrial injuries system or tort liability for work accidents. However, there are considerable changes proposed to the way in which tort claims

218 No 146 above. 
generally are funded and costs allocated. ${ }^{219}$ These changes are expected to have a major impact upon the number and type of cases litigated. ${ }^{220} \mathrm{By}$ contrast a wide-ranging Government consultation paper on the industrial injuries scheme in 2007 resulted in only very minor reforms. ${ }^{221}$

\section{F. Overall quality of each system independently and in combination}

\section{Why preferential compensation for workers?}

168 The quality and effectiveness of each system has been examined in detail above. But a final question must be asked. Both tort and the industrial injuries scheme offer easier routes to compensation to those injured at work as opposed to elsewhere. Workers can even claim under both schemes. Is this preference justified?222 This fundamental question lies at the heart not only of the future of welfare state provision but also compensation for personal injury in tort. How efficient and fair are our systems of compensation? For those who favour equal compensation for the same loss or injury no matter what the cause - and at an administrative cost which is not out of proportion to the monies distributed - much remains to be done.

169 This article is very unusual in comparing the system of compensation established by tort with an area of provision made by the welfare state. In providing details of how each system actually operates in practice and in supplying the relevant statistical data, this article employs techniques which it is hoped may appeal to others involved in the work of the European Centre of Tort and Insurance.

219 Lord Justice Jackson, Review of Civil Litigation Costs: Final Report (December 2009) considered in K Oliphant et al, On a Slippery Slope (2011) <http://ectil.org/oliphant/ slippery-slope/>.

220 R Lewis, Litigation Costs and Before-The-Event Insurance: The Key to Access to Justice? (2011) 74 MLR 272.

221 Department for Work and Pensions, The Industrial Injuries Disablement Benefit Scheme a Consultation Paper (2007) and Department for Work and Pensions, Consultation Report (2007).

222 Nos $12-15$ above. 